$$
\begin{array}{r}
\text { DOE/PETC/TR-96/4 } \\
\text { RECEIVED } \\
\text { SEP } 301996 \\
\text { OSTI }
\end{array}
$$

DOE/PETC/TR-96/4

\title{
A UTILITY SURVEY AND MARKET ASSESSMENT ON REPOWERING IN THE ELECTRIC POWER INDUSTRY
}

By

J.M. Klara

R.E. Weinstein

M.R. Wherley

August 1996

DISTPIBUTION OF THIS DOCUMENT IS UNLMTED. 


\section{DISCLAIMER}

Portions of this document may be illegible in electronic image products. Images are produced from the best available original document. 


\title{
RECEIVED SEP 30 1996 \\ OSTI
}

A Utility Survey and Market Assessment on Repowering in the Electric Power Industry

\author{
J.M. Klara \\ U.S. Department of Energy \\ Pittsburgh Energy Technology Center \\ P.O. Box 10940 \\ Pittsburgh, PA 15236 \\ R.E. Weinstein \\ Parsons Power Group Inc. \\ 2675 Morgantown Road \\ Reading, PA 19607
}

M.R. Wherley

Science Applications International Corporation

11251 Roger Bacon Drive

Reston, VA 22090 


\title{
A Utility Survey and Market Assessment on Repowering in the Electric Power Industry
}

\author{
August 1996 \\ Prepared by: \\ The United States Department of Energy \\ Pittsburgh Energy Technology Center \\ P.O. Box 10940 \\ Pittsburgh, Pennsylvania 15236
}

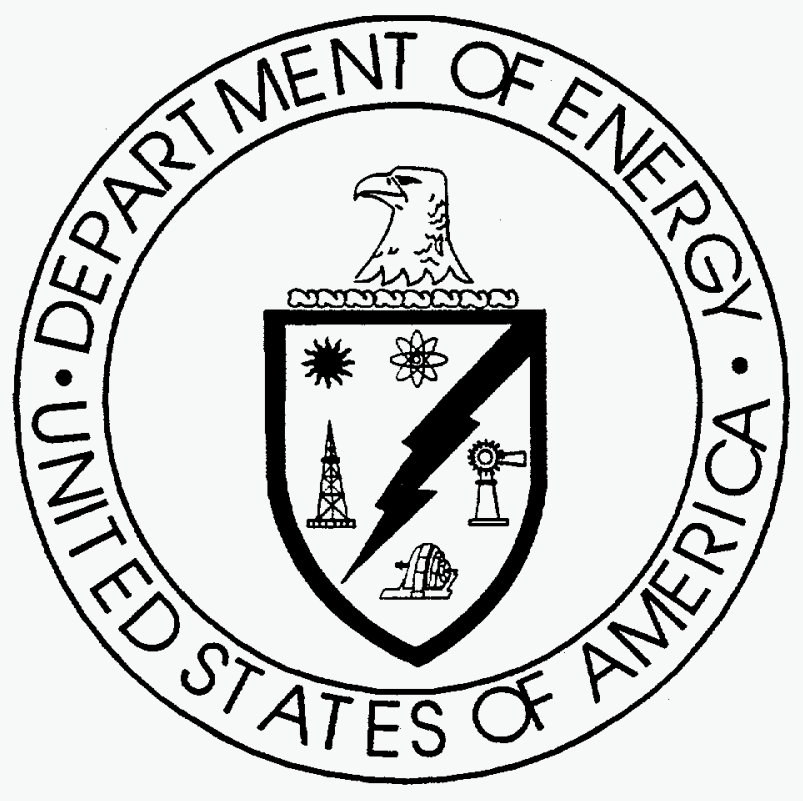

Project Manager: Julianne M. Klara U.S. DOE PETC

Authors:

Richard E. Weinstein Parsons Power Group Inc. Michael R. Wherley Science Applications International Corporation 


\section{NOTICE}

This report was prepared as an account of work sponsored by an agency of the United States Government. Neither the United States Government nor any agency thereof, nor any of their employees, makes any warrantee, express or implied, or assumes any legal liability or responsibility for the accuracy, completeness or usefulness of any information, apparatus, product or process disclosed, or represents that its use would not infringe privately owned rights. Reference herein to any specific commercial product, process, or service by trade name, trademark, manufacturer, or otherwise does not necessarily constitute or imply its endorsement, recommendation, or favoring by the United States Government or any agency thereof. The views and opinions of authors expressed herein do not necessarily state or reflect those of the United States Government or any agency thereof. 


\section{SUMMARY}

With the projected need for additional electric generating capacity in the U.S. and the age of many coal-fired steam plants, electric utilities are considering repowering existing generating units as a cost-effective option to extend unit life, improve efficiency, increase capacity, and comply with environmental regulations. To assess the electric utility thoughts about repowering, a U.S. Department of Energy (DOE) team comprised of government personnel and contractors developed a survey for the senior management of several electric utilities. This report provides the following:

- The results of a survey of planning executives from eight eastern and two mid-western electric utilities (see exhibit below). Their views on the concept of repowering existing electric generation units with technologies ranging from commercial to advanced are summarized.

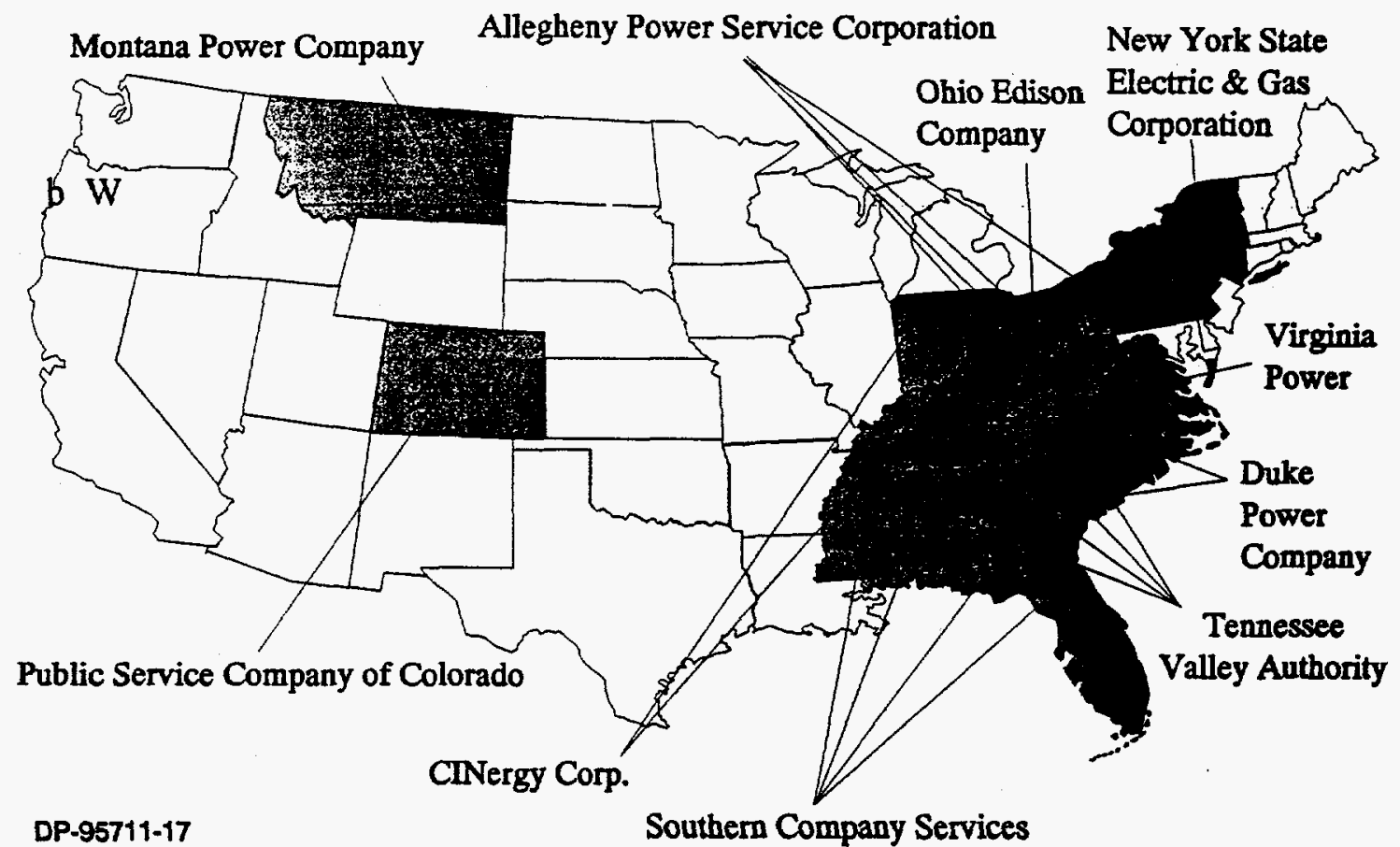

- A market assessment that identifies the types of units suited for repowering with either commercial technologies or advanced technologies that are under development by the U.S. Department of Energy (DOE).

\section{Repowering}

The Pittsburgh Energy Technology Center (PETC) of the U.S. Department of Energy (DOE) is supporting the development of two different classes of power systems: systems based on (1) the direct firing of pulverized coal, and (2) the indirectly fired cycle. The PETC program, which is called "Combustion 2000," comprises the engineering development of the Low Emission Boiler System (LEBS) - the direct-fired pulverized-coal-based system -- and the High Performance Power System (HIPPS) - the highly efficient, coal-based, indirectly fired combined cycle system. LEBS and HIIPS 
are intended primarily for new plants; however, DOE envisions that repowering applications may be the initial market entry for Combustion 2000 power cycles.

In a conceptual design study, "Repowering with High Performance Power Systems (HIPPS)," PETC evaluated several unit repowering options with HIPPS. This study provided research guidance to the HIPPS program, providing cycle development needs, economic feasibility, technology demonstration needs, risk assessment, and commercialization potential for a repowering application. In support of that evaluation, DOE performed this market assessment and utility survey to ensure that key questions and needs of electric utility companies were addressed.

\section{What This Report Contains}

Background. Section 1 of this report provides a background about the DOE HIPPS program. There are two kinds of HIPPS cycles under development. One team is led by the Foster Wheeler Development Corporation, the other team is led by the United Technologies Research Center. These cycles are described in Section 1.

Survey. Section 2 summarizes the feedback from the survey of the repowering needs of ten electric utility companies. The survey verified that the utility company planners favor a repowering for a first-of-a-kind demonstration of a new technology rather than an all-new-site application. These planners list the major factor in considering a unit as a repowering candidate as plant age: they identify plants built between 1955 and 1965 as the most likely candidates. Other important factors include the following:

- The need to reduce operating costs,

- The need to perform major maintenance/replacement of the boiler, and

- The need to reduce emissions.

A unit of less than 200 MW capacity is the most likely size to be considered for repowering by the electric utility industry. The survey responses also indicate that proven capability and competitive cost are mandatory. Capital cost must be reasonable and economics must be competitive as the industry responds to open access and moves toward decreased regulation and increased competition. The perceived risk factors that affect the decision to repower vary among the respondents. The strongest agreement relates to future price of natural gas, which respondents expect will escalate greatly after 2005 compared to the price of coal.

Market Assessment. Section 3 reports the results of the market assessment. Using the size and age preferences identified in the survey, a market assessment was conducted (with the aid of a power plant data base) to estimate the number and characteristics of U.S. generating units which constitute the current, primary potential market for coal-based repowering. Nearly 250 units in the U.S. meet the criteria determined to be the potential repowering market. 


\section{TABLE OF CONTENTS}

\section{A Utility Survey and Market Assessment on Repowering in the Electric Power Industry}

Section

Title

Page

NOTICE

SUMMARY

ii

LIST OF EXHIBITS

vi

ACKNOWLEDGEMENTS

vii

1 BACKGROUND

1.1 The DOE HIPPS Program 1-1

1.2 The New Electric Generation Market 1-2

2 UTILITY COMPANY SURVEY 2-1

2.1 Survey Objectives 2-1

2.2 Survey Participants $2-4$

2.3 How the Information is Summarized 2-6

2.4 What Motivates Consideration of Repowering? 2-7

2.5 What Makes a Specific Unit a Candidate? 2-11

2.6 What Repowering Technology Attributes Are Important? 2-12

2.7 What Type of Repowering Method Is Attractive? 2-15

2.8 What Risk Factors Affect the Decision? 2-20

2.9 Sensitivity of Unit Dispatch to Operating Costs 2-22

2.10 Summary of Survey Results 2-23

3 MARKET ASSESSMENT 3-1

3.1. Data Source for Market Assessment 3-1

3.2 Pre-Selection Criteria 3-1

3.3 Unit Age and Size 3-3

3.4 Reheat versus Non-Reheat 3-6 
3.5 Throttle Pressure

3-7

3.6 Throttle Temperature

3-8

3.7 Representative Plant Population for Repowering

4 REFERENCES 


\section{LIST OF EXHIBITS}

Exhibit

Title

Page

Exhibit 1 Electric Utility Company Return Before and After Deregulation

Exhibit 2 U.S. Plant Efficiency Versus Year Installed

Exhibit 3 Characteristics of the Survey Participants

Exhibit $4 \quad$ States Served by the Participants in the Electric Utility Company Survey

Exhibit 5 Reasons For Considering Repowering

Exhibit 6 Important Technology Attributes

Exhibit 7 Preferences for Method of Repowering

Exhibit 8 Perceptions on Risk Factors

Exhibit 9 Perceptions on a HIPPS Demonstration Project

Exhibit 10 Typical Operating Costs versus Annual Hours of Operation

Exhibit 11 Fossil Plant Generation Capacity versus Year of Startup

Exhibit 12 Number of U.S. Coal Units Sorted by Size

Exhibit 13 Number of Presently-Operating U.S. Coal-Fired Units by Age and Size

Exhibit 14 Prevalence of Reheat in U.S. Power Plants

Exhibit 15 Throttle Pressure of Coal-Fired Units

Exhibit 16 Superheat Temperature of Coal-Fired Units 


\section{ACKNOWLEDGEMENTS}

This report was prepared by the United States Department of Energy. It was prepared with the support of a number of persons both within the Department and from industry contractors. Key contributors to this report include:

Project Manager:

Julianne M. Klara

U.S. DOE, PETC

Authors:

Richard E. Weinstein, P.E.

Parsons Power Group Inc.

Michael R. Wherley

Science Applications International Corp.

Other significant contributors include:

Lawrence E. Van Bibber

Parsons Power Group Inc.

Jon $\mathrm{H}$. Ward

Science Applications International Corp.

This report could not have been prepared without the excellent cooperation of the electric utility companies that participated in the survey. These participants are acknowledged in Section 2.2. 


\section{BACKGROUND}

\subsection{THE DOE HIPPS PROGRAM}

Anticipating the need for new generation capacity in the U.S., the Pittsburgh Energy Technology Center (PETC), a field office of the U. S. Department of Energy (DOE), developed the Combustion 2000 program. This program strives to assure that the U.S. can economically continue to use its extensive coal resources to meet future power-generating needs by improving efficiency, emissions control, and cost with innovative technologies suited for both building new and repowering existing power plants. The Combustion 2000 program consists of two systems: the Low-Emission Boiler System (LEBS) and the High Performance Power System (HIPPS).

LEBS uses highly advanced combustion, emission control, and power cycle technology that will help electric generating companies add new coal-fired base-load capacity, or repower existing plants, beginning after the year 2000. The LEBS goals include decreased emissions, increased efficiency, and similar capital costs as compared to today's coal-fired power plants.

HIPPS, targetted for a later introduction (2004), is aimed at developing advanced coal-based power systems using an indirectly-fired gas-turbine that offer significant improvements over today's conventional power plants. The HIPPS goals are more aggressive than those of LEBS: major improvements in thermal efficiency, environmental performance, and cost of electricity.

Other technologies, such as gasification and pressurized fluidized-bed combustion, are alternatives to HIPPS; however, the HIPPS concept has the advantage of similarity in design to a conventional pulverized-coal plant. The environmental performance for the HIPPS systems are excellent (less than 1/10 of what New Source Performance Standards allow today) compared to today's coal-fired units. HIPPS emission reductions far exceed that of a modern pulverized-coal plant with conventional flue gas treatment at reduced capital investment. ${ }^{1,2}$

Through a competitive solicitation issued in September 1990, two teams headed by Foster Wheeler Development Corporation (FWDC) and United Technologies Research Center (UTRC) were contracted by DOE to develop HIPPS. These teams completed Phase 1 activities that included preliminary research and development, engineering analysis, and experimental testing. An open solicitation (not limited to the two industry teams involved in Phase 1) for Phases 2 and 3 of the engineering development of HIPPS was issued in April 1994, and awards were made in June 1995. Both FWDC and UTRC were selected to continue the development of their concepts. Phase 2 entails engineering development and subsystem testing at a moderate scale and the site-specific engineering design of a prototype plant. Phase 3 includes the design of a prototype plant, followed by plant construction, testing and evaluation.

DOE/PETC envisions that repowering applications may be the initial market entry for HIPPS technology. If the initial demonstration of this technology proves successful, then a number of repowering project replicates would launch HIPPS and develop market demand for both repowering and new site applications. 


\subsection{THE NEW ELECTRIC GENERATION MARKET}

Public policy is rapidly pushing the electric power industry away from its former regulated monopoly structure and toward unprecedented competition. The industry is adjusting to new ways of doing business as it moves to open transmission access and responds to the implications of increased competition, as evidenced by recent major restructuring, price structure adjustments, and operating changes. The price of electricity will be set by market forces, rather than tariffs set by rate cases. Generation companies will need to minimize capital and production costs in order to generate a profit with no certainty of an assured minimum return (see Exhibit 1).

Exhibit 1.

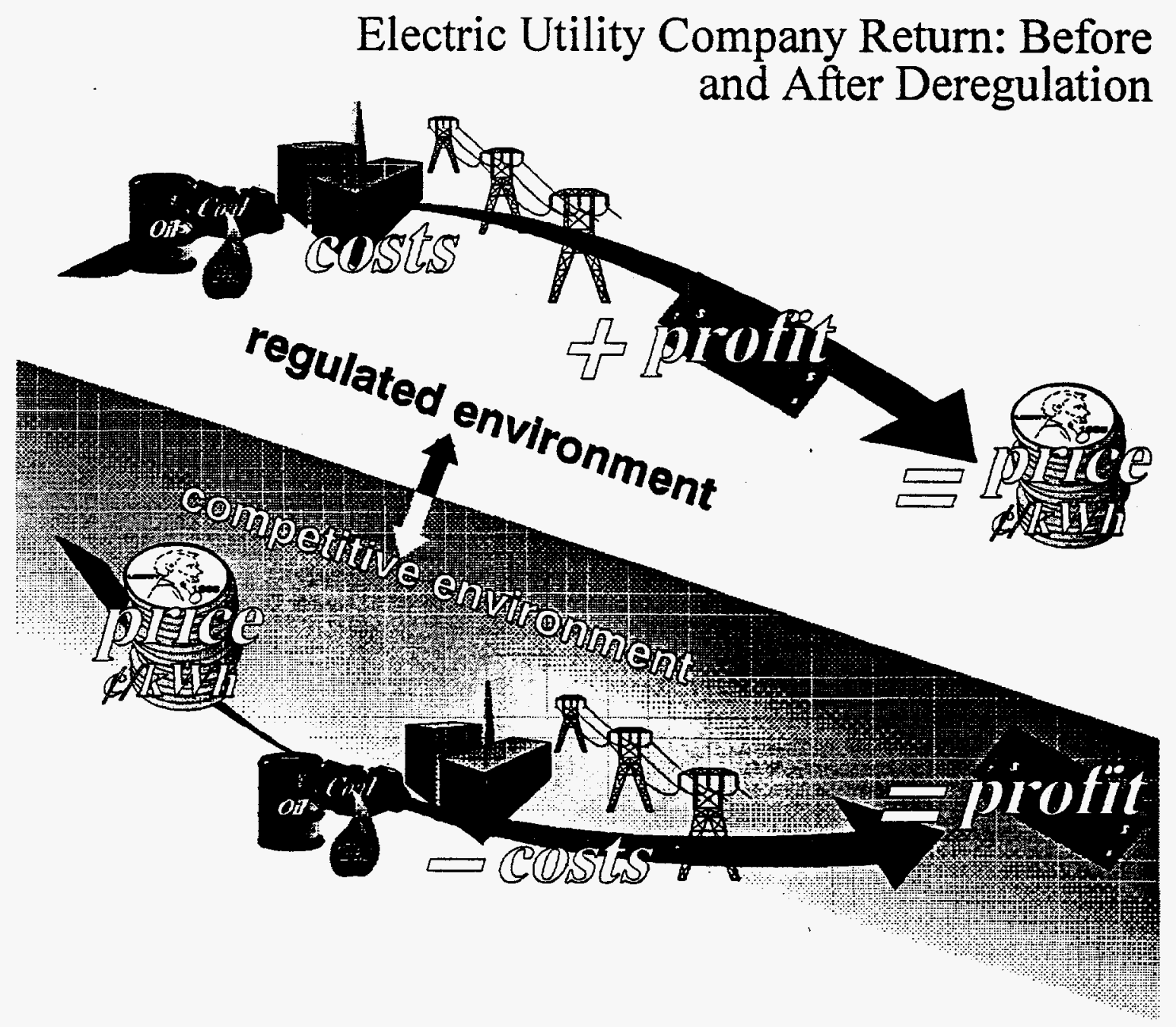

At the same time, increasingly stringent environmental regulations demand that units operate with exemplary emissions characteristics. These and other market forces impel generating companies to consider the purchase of new or upgraded generation with characteristics that meet goals similar to those of PETC's Combustion 2000 program: 
- New generation technology that is reliable, very clean, easy to operate, and inexpensive to maintain.

- Technology that has a competitive cost.

- Technology that is highly efficient, and able to operate at low production cost using a reliable supply of abundant, low-price domestic fuel.

Combined cycles, most often fueled by natural gas, are in high demand today because of their high efficiency, good reliability, and the present competitive price of natural gas. However, the U.S. has huge reserves of coal, which is a lower priced fuel than natural gas. Thus, there is a desire to fuel combined-cycles with coal (without damaging the gas turbine) at a competitive cost. PETC has been developing HIPPS to meet this objective. 
On behalf of DOE, seventeen utilities were contacted to participate in a survey concerning the repowering of electric generating units. Of the fourteen utilities that agreed to participate in the survey, ten responded to the questions on repowering issues. The survey objectives and the respondent's characteristics are described in Sections 2.1 and 2.2. Sections $2.3-2.10$ contain the results of the survey.

\section{$2.1 \quad$ SURVEY OBJECTIVES}

The objective of the survey was to gather information about where repowering fits into the plans of regulated electric utility companies, and what considerations are important to them when considering a repowering technology option. The survey requested feedback on the following issues:

- What factors are most important for considering repowering as an option?

- What makes a specific unit likely or unlikely for consideration for repowering?

- What considerations are important for selecting a particular repowering technology?

- What type of repowering method is attractive?

- What are the risks (future fuel costs, externalities, deregulation) that affect the decision?

- What level of risk is suggested as acceptable for a first-of-a-kind technology demonstration?

- What should be the major emphasis of an advanced technology repowering demonstration?

- What are the principal technical concerns about advanced technologies?

- What is the sensitivity of unit dispatch to operating costs?

In preparing the utility survey, the DOE/PETC study team reviewed the typical motivations for repowering and the factors pertinent to evaluating a potential repowering site. This information is summarized below.

\subsubsection{Motivations for Repowering}

Companies with aging generating units consider repowering for a number of reasons:

a. The need for added capacity on the system either to meet local demands or for longdistance retail wheeling.

b. The need to make the unit more competitive. Improving heat rate can reduce generating costs. This can improve a unit's position in the dispatch order and thereby increase its capacity factor.

c. The need to reduce environmental emissions to comply with local regulations and the Clean Air Act and its amendments. 
d. The need to replace major equipment. Repowering with new equipment can be more cost-effective than extensive refurbishment.

\subsubsection{Factors Influencing the Implementation of Repowering}

Evaluation of the potential for repowering a particular facility involves consideration of numerous factors. Every site requires a site-specific evaluation of these issues. At a minimum, the following site- and plant-related factors must be evaluated.

a. Overall Condition and Potential for Life Extension. The condition of the infrastructure of the plant, such as roads and civil works, steam turbine generator, and ancillary equipment is an important consideration in determining the amount of equipment that can be retained in service, or economically refurbished. Any equipment and infrastructure that can be preserved reduce the capital investment required.

b. Cycle Integration Compromises Must Be Modest. Repowering is most attractive when the amount of preserved equipment is large, and the power-cycle integration needed to fit new equipment to the existing process does not significantly compromise performance advantages. Trying to match a repowering process to existing equipment frequently involves a compromise in heat rate that would not exist if all new equipment were selected. The performance loss incurred to preserve the existing equipment must be evaluated against the capital savings.

c. Present and Repowered Generating Capacity. The repowering technology must be compatible with the existing unit size while providing the desired final capacity. Some advanced technologies are scalable over a wide range of sizes. Others are modular and come in discrete sizes. These issues are significant in determining the economic efficiency of the repowering scheme, and mismatches will impair the economic attractiveness of repowering.

d. Match to Existing Steam Turbine. When the existing steam turbine/generator is retained, the repowering technology must be matched in size to provide the necessary steam requirements. If the repowering approach increases the amount of low temperature heat available for economizer duty, feedwater heaters can be taken out of service, increasing the amount of steam flow available for power generation. If the steam turbines do not have the back-end capacity to handle the added steam, the throttle steam flow must be reduced so back-end flow limits are not exceeded.

e. Fuel Use. Repowering may be based on continued use of the current fuel, the return to a previously-used fuel, or the introduction of a "new" fuel (examples include replacing oil with either natural gas or coal, or introducing a new process-derived fuel). The selection of the appropriate fuel for repowering depends on the specific repowering technology, overall economics, and on the capabilities of the site and regional infrastructure to supply that fuel.

f. Heat Rate and Operating Cost, Present and Repowered. Fuel costs represent the largest operating cost for fossil-fueled facilities. The change in heat rate and the change in fuel costs (where a fuel change is made), along with the costs of required chemicals and sorbents, are 
very important in repowering economics. Normally, the repowered unit will operate at an improved heat rate or with a lower-cost fuel and, therefore, can obtain a higher dispatch priority and increased annual use. The improved dispatch will significantly improve the cost of electricity and return on investment. It may also significantly reduce the number of unit start-stop thermal fatigue and pressure fatigue cycles, thus reducing maintenance costs.

Exhibit 2 shows the net plant efficiency of the U.S. generating fleet versus the year installed. There has been little improvement in plant efficiency since the 1960s. This is largely due to the installation of pollution control equipment and the increased use of cooling towers. These increase auxiliary load and steam turbine back pressure, respectively, which tends to offset any improvement in the generation equipment. Although higher efficiency equipment that uses higher steam cycle conditions is within technical capabilities, their use is not economical in the U.S. currently. A new generation of advanced technologies is needed to increase energy efficiency at reduced cost and risk.

Exhibit 2

U.S. PLANT EFFICIENCY VERSUS YEAR INSTALLED ${ }^{3}$

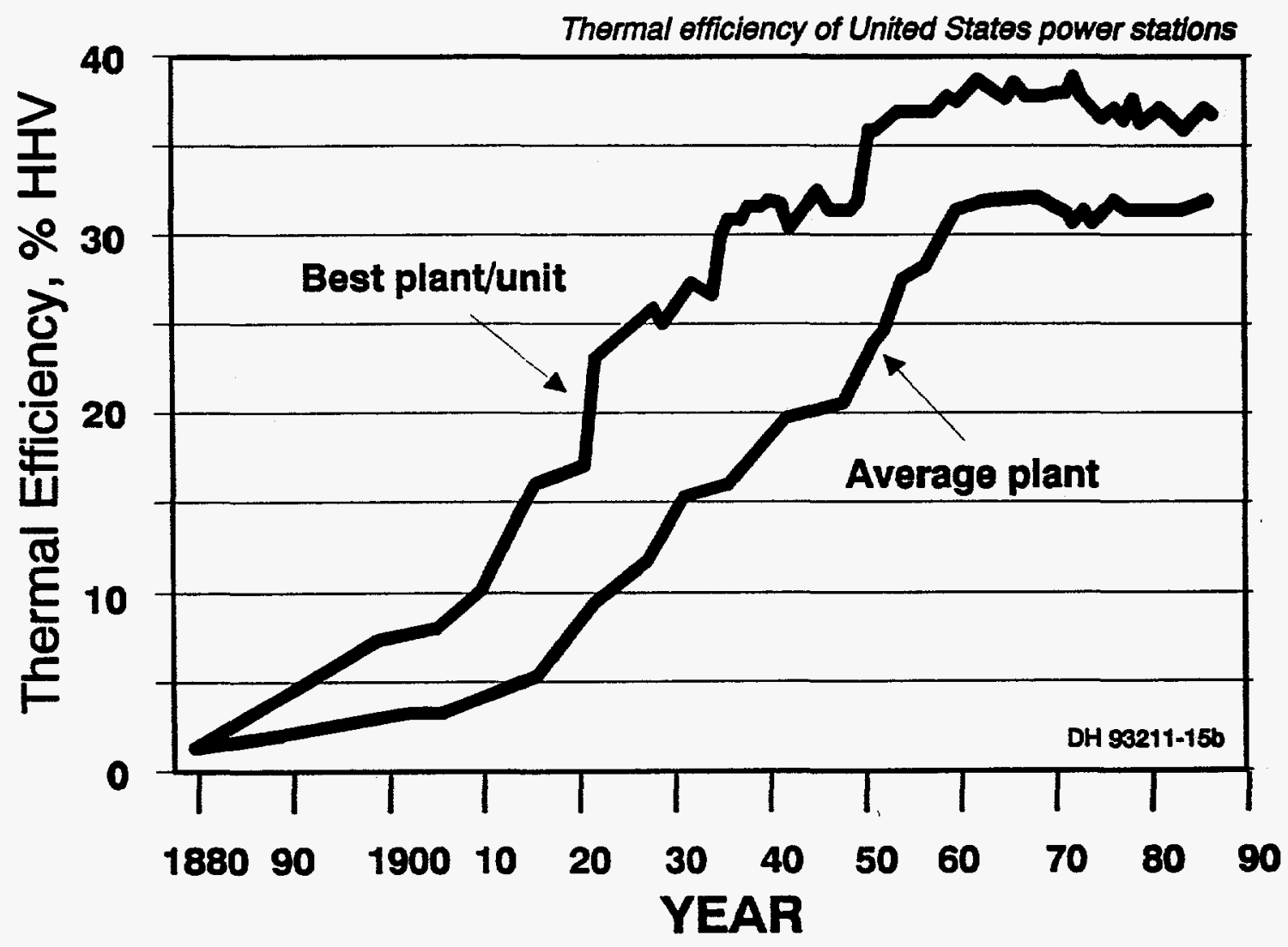


g. Site Adaptability/Space/Access. Candidate repowering sites must have space to accommodate new structures, facilities, and equipment. There must also be adequate space for laydown and construction access. Space for fuel access and storage must also be considered.

h. Outage Period Needed. The construction time required to complete the repowering upgrade must be within a scheduled outage since the cost of replacement power bought during the upgrade could be significant.

i. Environmental Emissions, Present and Repowered. Reduction of air emissions (such as $\mathrm{SO}_{x} \mathrm{NO}_{x}$ particulate matter, air toxics and (perhaps) $\mathrm{CO}_{2}$ ) to meet environmental regulations is often one of the main motivating factors to repowering.

j. Transmission Capacity/Proximity to Major Load Centers. Since repowering is likely to increase capacity, additional transmission capacity may be needed. Expansion of the transmission right-of-way can be expensive and may significantly change the economics of repowering a site with a designated technology.

\subsection{SURVEY PARTICIPANTS}

The companies invited to participate in the survey were selected on the following basis:

- Having participated or cooperated in prior DOE projects, or

- Having indicated an interest in DOE's HIPPS Program through past meetings or contact, or

- Having coal-fired units in the 100-300 MW range, which was determined by the DOE/PETC study team to be a favorable plant size for repowering.

Seventeen utilities were contacted to determine their interest in HIPPS and in participating in a survey about repowering. Of those contacted, ten utilities (listed in Exhibit 3) responded. The various states served by these companies are illustrated in Exhibit 4. 
Exhibit 3

CHARACTERISTICS OF THE SURVEY PARTICIPANTS

\begin{tabular}{|c|c|c|c|c|c|}
\hline \multirow{2}{*}{$\begin{array}{c}\text { Company } \\
\text { States Served }\end{array}$} & \multirow{2}{*}{$\begin{array}{c}1994 \\
\text { Installed } \\
\text { Capacity } \\
\text { MWe }\end{array}$} & \multirow{2}{*}{$\begin{array}{c}1994 \text { Total } \\
\text { Generation } \\
\text { MWh }\end{array}$} & \multicolumn{3}{|c|}{$\begin{array}{l}\text { Contribution by Fuel, } \\
\text { as Percent of } 1994 \text { Total Generation }{ }^{5}\end{array}$} \\
\hline & & & Coal & Natural Gas & Other \\
\hline $\begin{array}{l}\text { Allegheny Power System, } \\
\text { Inc. } W V, O H, V A, P A\end{array}$ & 7,933 & $40,460,364$ & $99.12 \%$ & $0.07 \%$ & $0.81 \%$ \\
\hline CINergy Corp. OH, IN & 11,155 & $52,736,622$ & $98.66 \%$ & $0.25 \%$ & $1.09 \%$ \\
\hline $\begin{array}{l}\text { Duke Power Company } \\
\text { NC, SC }\end{array}$ & 18,227 & $84,974,238$ & $38.29 \%$ & $0.03 \%$ & $61.68 \%$ \\
\hline $\begin{array}{l}\text { Montana Power Company } \\
\qquad M T\end{array}$ & 1,226 & $8,136,719$ & $62.30 \%$ & $0.61 \%$ & $37.09 \%$ \\
\hline $\begin{array}{c}\text { New York State Electric \& } \\
\text { Gas Corporation NY }\end{array}$ & 2,591 & $9,127,175$ & $96.35 \%$ & n/a & $3.65 \%$ \\
\hline Ohio Edison Company OH & 5,362 & $17,647,769$ & $99.81 \%$ & $\mathrm{n} / \mathrm{a}$ & $0.19 \%$ \\
\hline $\begin{array}{l}\text { Public Service Company of } \\
\text { Colorado CO }\end{array}$ & 3,369 & $16,922,135$ & $98.16 \%$ & $1.22 \%$ & $0.62 \%$ \\
\hline $\begin{array}{l}\text { Southern Company Services } \\
A L, G A, F L, M S\end{array}$ & 30,156 & $173,359,859$ & $70.41 \%$ & $0.94 \%$ & $28.65 \%$ \\
\hline $\begin{array}{l}\text { Tennessee Valley Authority } \\
T N, A L, N C, K Y\end{array}$ & 30,714 & $126,546,009$ & $70.91 \%$ & $0.11 \%$ & $28.98 \%$ \\
\hline Virginia Power VA, NC & 13,133 & $55,080,755$ & $45.69 \%$ & $3.91 \%$ & $50.40 \%$ \\
\hline
\end{tabular}

notes: a: such as hydroelectric, nuclear, oil, etc.

na: not applicable, no capacity listed in this category

The utility representatives responding to the questionnaire were senior planners qualified to provide authoritative answers. The job titles of those responsible for responding to the surveys included:

- Associate Planning Engineer

- Director, Corporate Technical Assessment

- Director, Thermal Engineering

- Director, Generation Planning

- Engineer, Research \& Development

- General Manager, Engineering

- General Mechanical Engineer, Generating Plant Engineering Department

- Key Account Manager, Gas Business Unit
- Manager, Strategic Generation

- Manager, Technical Services

- Manager, Station Operations

- Manager, Mechanical Engineering

- Manager, Electrical and I/C Engineering

- Manager, Research \& Development

- Principal Engineer, Combustion Turbine Technologies

- Project Engineer, Electric Supply Planning \& Procurement

- Specialist, Generation Technology 


\section{Exhibit 4 \\ STATES SERVED BY THE PARTICIPANTS \\ IN THE ELECTRIC UTILITY COMPANY SURVEY}

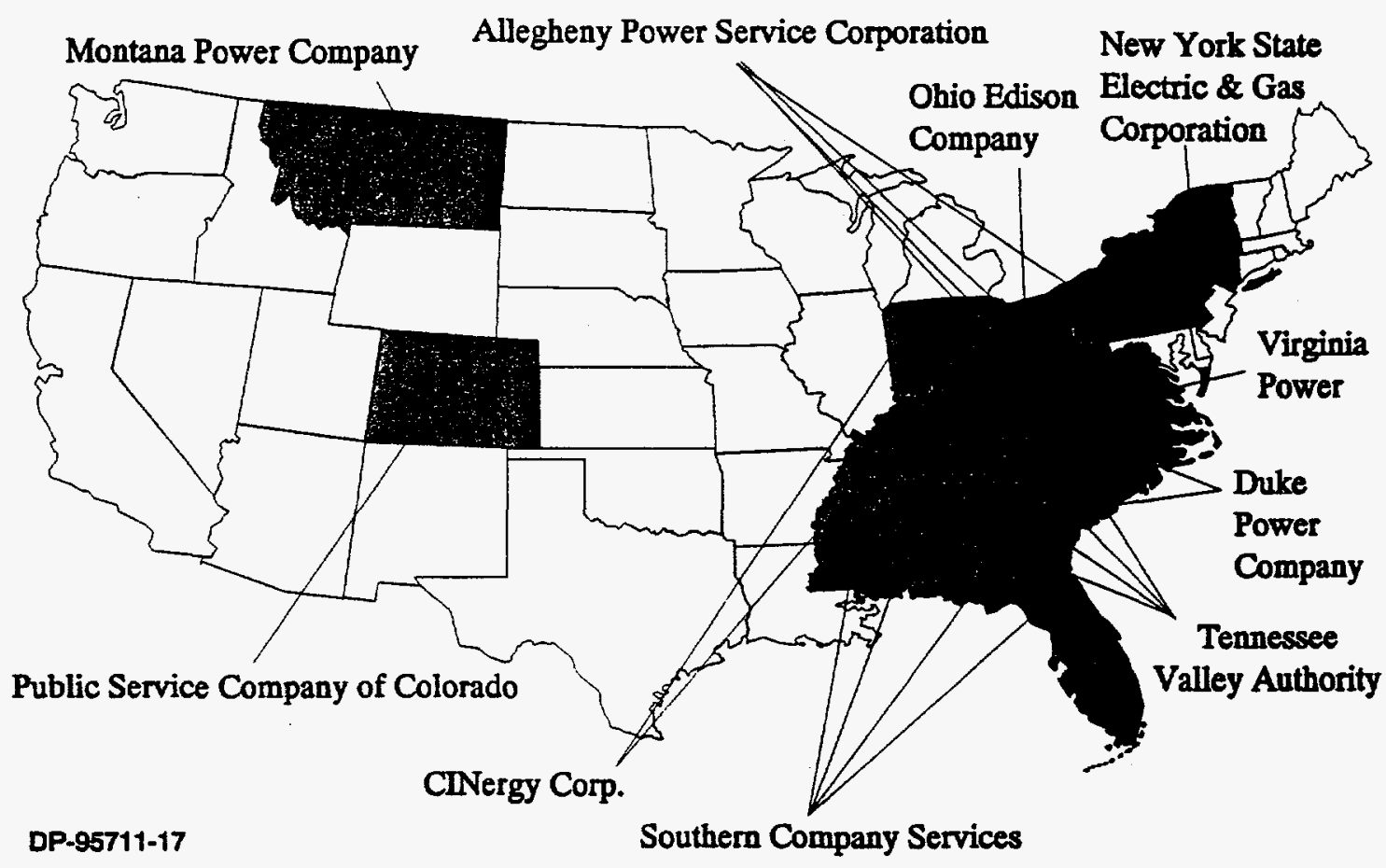

\subsection{HOW THE INFORMATION IS SUMMARIZED}

The remaining subsections discuss the major points made by the utility company participants in the survey. Selective responses are listed here to highlight the significant results, and some narrative comments have been summarized for clarity. Specific responses of the individual company are not identified. Major conclusions from the survey are listed in subsection 2.10.

To aid in the interpretation of the survey results, both numerical and graphical presentation format is used. An example of this format is shown on the following page: 


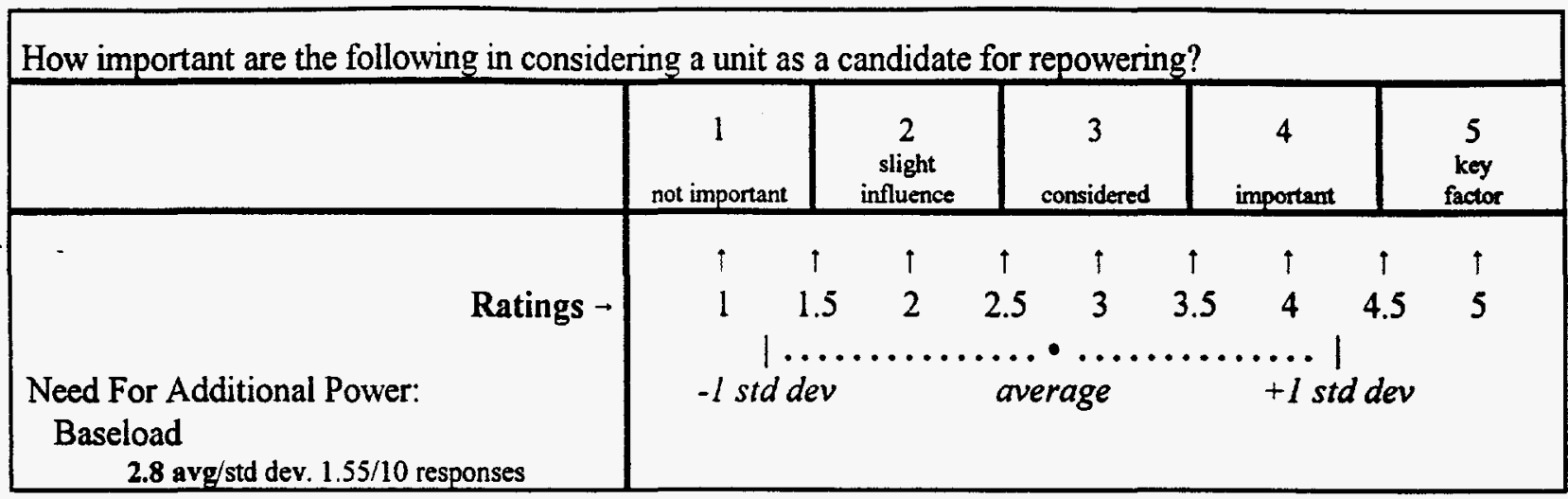

The left-most block ("not important") is assigned a rating of 1, the "slight influence" block a rating of 2 , "considered," a rating of 3 , and so forth. The number of responses in each block is multiplied by the rating, and the totals are averaged. Note that the center of each box is the location of the valuation; thus "slight influence" has a value of 2.0 at the center of that box, while 2.5 is the edge of the box.

The standard deviation of the answers provides a good measure of the degree of consensus. For the above example, the standard deviation is 1.55 . The average is displayed by a bullet $(\bullet)$, with bars to the left and right showing one standard deviation below and above the average, respectively. A contentious issue will have a wide spread, while a consensus issue will have a narrow spread. In the example, the average is shown as 2.8 , with bars bounding \pm 1 standard deviation ( \pm 1.55$)$, that is, from 1.25 to 4.35 . This issue is a contentious one, with a very wide band of disagreement among those responding.

In most sections, the responses are listed in descending order of importance to the utility companies, rather than in the order the questions were asked.

\subsection{WHAT MOTIVATES CONSIDERATION OF REPOWERING?}

Exhibit 5 summarizes the reasons that utilities consider repowering. The age of the unit is the highest-ranked reason. Improved costs and reduced emissions also ranked high. The size of the existing plant is not a very significant reason to repower. The needs for summer and winter peaking have only a slight influence on the choice to repower.

2.4.1 Age of Candidate Units. Shown below are the utility responses regarding age, indicating that the units preferred for repowering would have reached an average age of 40 years, and that any unit under 25 years of use would not be repowered. 


\begin{tabular}{|l|l|}
\hline $\begin{array}{l}\text { Age range most likely considered as } \\
\text { repowering candidate? }\end{array}$ & $\begin{array}{l}\text { Age range least likely considered as a repowering } \\
\text { candidate? }\end{array}$ \\
$\begin{array}{l}\text { - } 40 \text { to } 50 \text { years } \\
\text { older than } 45 \text { years, }\end{array}$ & - less than 30 years \\
- 45 years & - less than 35 years \\
- older than 40 years & \\
- older than 35 years & \\
- 35 to 45 years & \\
- 30 to 40 years & \\
\hline
\end{tabular}




\section{Exhibit 5 \\ REASONS FOR CONSIDERING REPOWERING}

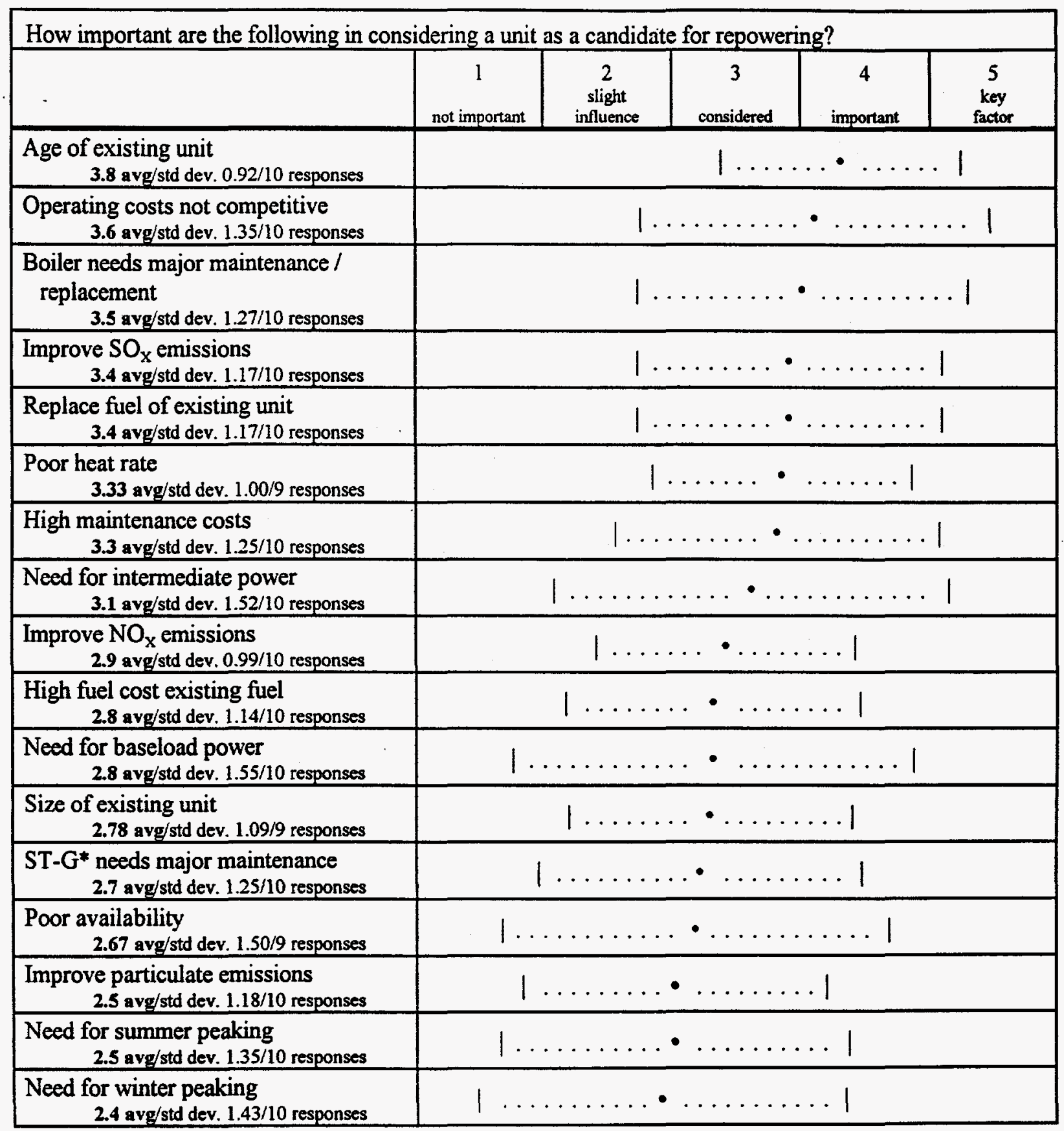

*ST-G = Steam turbine-generator 
2.4.2 The Desire to Change Fuel. The need to change fuel can be an important motivator for repowering. The surveyed utilities identified the fuel changes most likely to be made as part of a repowering. Notice the diversity of opinion about natural gas versus coal: some companies would like to switch from coal, others would like to switch to coal. Basically, gas is preferred because of its environmental performance and coal because of its low cost.

\section{Present fuel most likely to be replaced?, and Why is this fuel undesirable?}

- Coal

-- $1990 \mathrm{CAAA} *$ (environmental)

-- High $\mathrm{SO}_{x}, \mathrm{NO}_{x}$, (However, coal does have ample supply at low cost)

-- If natural gas becomes cost competitive

-.- Coal units are 45 years old

- Oil

-- Cost

-- $\mathrm{SO}_{2}$ emissions

- Nuclear

-- Unit needs to be replaced: never ran at full capacity

Fuel most desired for the replacement?, and Why is this fuel desired?

- Gas

-- 1990 CAAA* (environmental)

-- Very low emissions (but high cost)

-- Efficiency

-- Reduction in air emissions outweigh fuel costs

- Coal

-- Low cost

-- If can get lower emissions

- Not decided -- site dependent; depends on cost and availability

*CAAA $=$ Clean Air Act Amendments

2.4.3 Nameplate Rating of Candidate Units. The utilities surveyed listed the following as the most and least likely unit sizes that would be candidates for repowering. Generally, respondents considered units of 50 to $200 \mathrm{MW}$ as likely candidates: 


\section{Nameplate rating(s, or range) most likely} to be considered?

- greater than $50 \mathrm{MW}$

- $100 \mathrm{MW}$,

- 40 to $120 \mathrm{MW}$

- $44 \mathrm{MW}, 130 \mathrm{MW}$

- less than $150 \mathrm{MW}$

- 40 to $160 \mathrm{MW}$

- $163 \mathrm{MW}$

- 60 to $250 \mathrm{MW}$

- less than $200 \mathrm{MW}$

\section{Nameplate rating(s, or range) least likely} to be considered:

- units less than $40 \mathrm{MW}$

- units less than $50 \mathrm{MW}$

- units larger than $200 \mathrm{MW}$

- units larger than $250 \mathrm{MW}$

- units larger than $300 \mathrm{MW}$

- units larger than $500 \mathrm{MW}$

- units larger than $400 \mathrm{MW}$

- $600 \mathrm{MW}$

\subsection{WHAT MAKES A SPECIFIC UNIT A CANDIDATE?}

The survey asked what other characteristics would make a unit likely to be considered as a repowering candidate.

- Equipment. The steam turbine/generator, condenser/circulating water system and related balance-of-plant equipment are in relatively good condition. Repowering makes sense where major maintenance requirements exist for the boiler, but not the steam turbine/generator. The amount of balance-of-plant (BOP) facilities that can easily be incorporated into repowering and the ability of the unit/size to be incorporated into a combined cycle are important.

- Costs. Small coal-fired units with high operating costs are likely candidates. Another utility mentioned that any unit (big or small) with high operating costs is a candidate for repowering.

- Permitting. Repowering an existing unit would be easier to permit than a new "greenfield" unit. Also, repowering may provide a means to adhere to permit changes mandated by public utility commission.

- Emissions. Any emissions benefit from repowering would be welcome but are not key drivers in the decision process.

- Fuel. If a natural gas technology is used, the gas needs to be available with little or no pipeline additions. Also, repowering can increase a unit's fuel flexibility.

- Cycling. Units with a significant number of stop-start cycles are desirable candidates since repowering may reduce the number of unit start-stop cycles, thus reducing maintenance costs.

- Switchyard/Transmission. It is important that the switchyard is compatible with the repowering configuration, and that little or no transmission system upgrade is required. 
- Space. Adequate space for repowered plant configuration is necessary.

- Location. Location of plant is important: wilderness area, metropolitan areas.

Equally important is what the companies feel makes a unit unlikely to be a candidate for repowering. Their edited responses included:

- New plants. Current baseload units with high capacity factors and high availability have low heat rates and good emissions.

- BOP life. If there is little remaining life in the balance of plant facilities, there is little merit.

- Emission restrictions. If emissions/discharge restrictions are not amenable, the plant will not be repowered.

\subsection{WHAT REPOWERING TECHNOLOGY ATTRIBUTES ARE IMPORTANT?}

Important technology attributes for repowering were ranked by the utilities and are shown below. Survey responses indicate that proven capability and competitive cost are mandatory. 


\section{Exhibit 6}

\section{IMPORTANT TECHNOLOGY ATTRIBUTES}

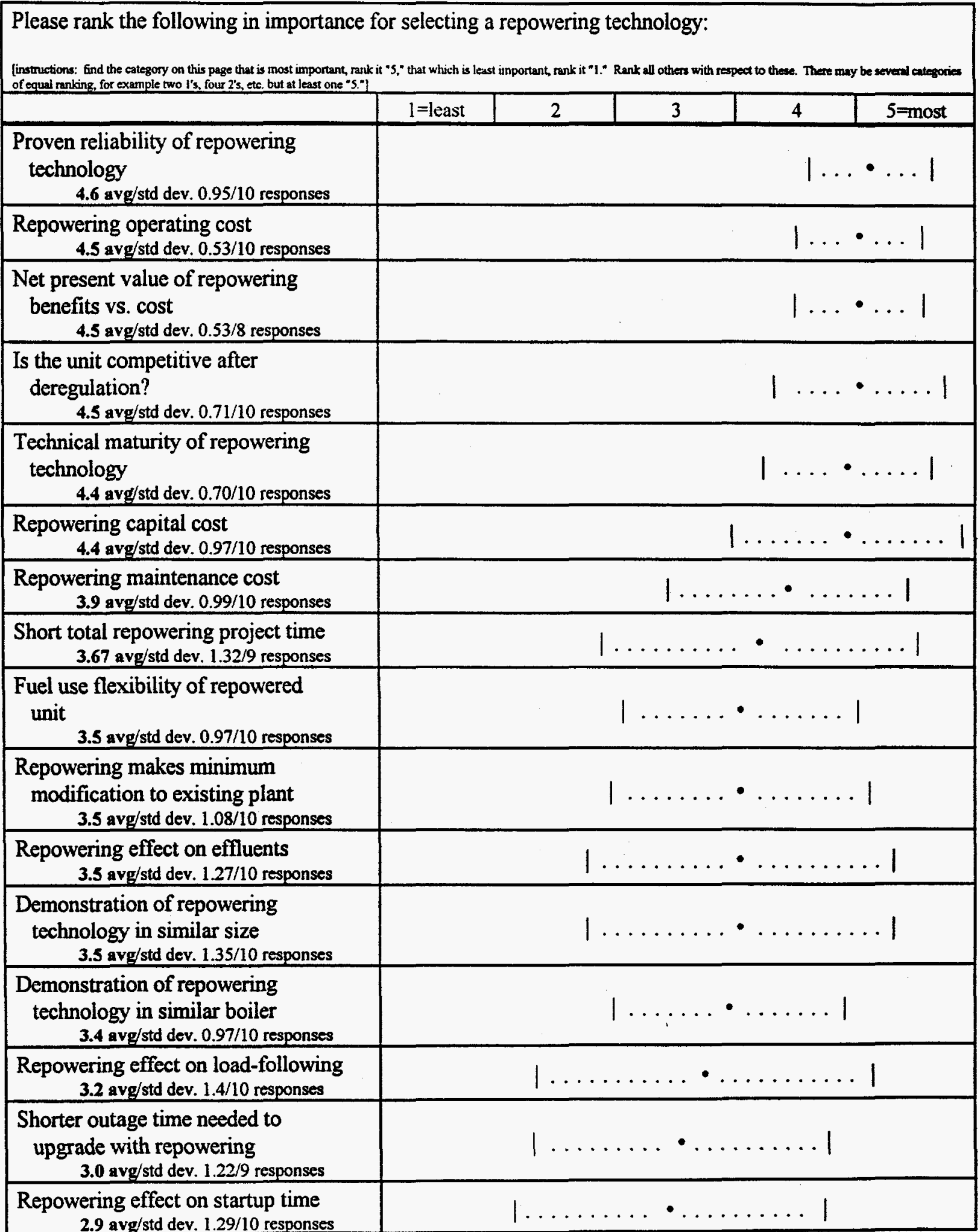




\begin{tabular}{|c|c|c|c|c|c|}
\hline \multirow{2}{*}{ 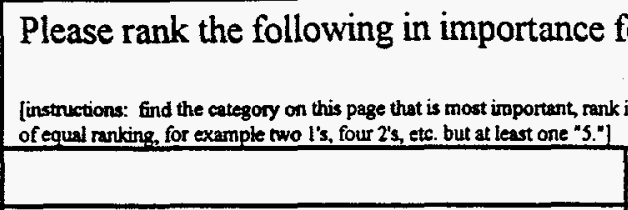 } & $\begin{array}{l}\text { selecting } \\
\mathrm{s} \text {, that which is }\end{array}$ & wer & 10 & & \\
\hline & $1=$ least & 2 & 3 & 4 & 5 \\
\hline \multicolumn{6}{|l|}{$\begin{array}{l}\text { Repowering technology } \\
\text { manufacturer reputation } \\
2.9 \text { avg/std dev. } 1.45 / 9 \text { responses }\end{array}$} \\
\hline \multicolumn{6}{|l|}{$\begin{array}{l}\text { Regulatory body pressure to select } \\
\text { repowering technology } \\
2.89 \text { avg/std dev. } 1.45 / 9 \text { responses }\end{array}$} \\
\hline \multicolumn{6}{|l|}{$\begin{array}{l}\text { Reduced repowering licensing } \\
\text { lead time } \\
\mathbf{2 . 4 4} \mathbf{~ a v g / s t d ~ d e v . ~ 1 . 3 3 / 9 ~ r e s p o n s e s ~}\end{array}$} \\
\hline $\begin{array}{l}\begin{array}{l}\text { Effect of repowering on salable } \\
\text { by-products } \\
1.5 \text { avg/std dev. } 0.97 / 10 \text { responses }\end{array} \\
\end{array}$ & & & & & \\
\hline
\end{tabular}




\subsection{WHAT TYPE OF REPOWERING METHOD IS ATTRACTIVE?}

Shown below are the methods of repowering that survey participants felt were attractive. This table is followed by a listing of the favorable and unfavorable features of each option, as identified by the respondents.

\section{Exhibit 7}

\section{PREFERENCES FOR METHOD OF REPOWERING}

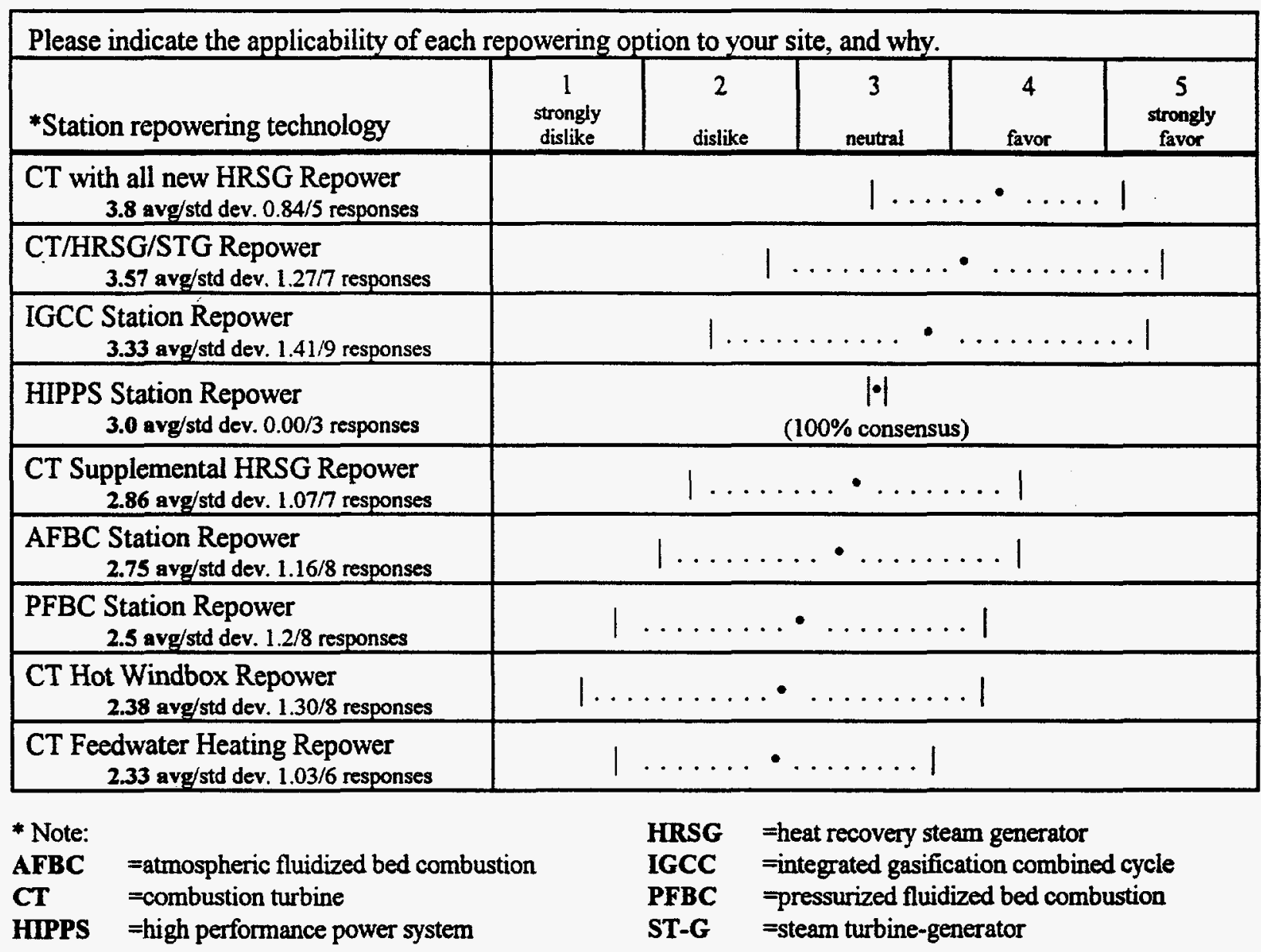


1st Ranked (Most Favored Method): All-new-HRSG Repower

Favorable Comments

- Overall economics based on cost and cycle efficiency

- This is our unit's second phase: a combustion turbine/HRSG

2nd Ranked: CT/HRSG/ST-G Repower

\section{Favorable Comments}

- It is possible that the existing steam turbine-generator not developed yet for coal

- Low capital cost

- Large capacity gain

- Very low emissions

- Proven technology and reliable operation

- Overall economics - good cycle efficiency, moderate cost aided by utilizing existing site, low emissions

- Familiar technology

- In some cases can use existing ST-G or CT or HRSG

- Ability to proceed in steps

3rd Ranked: Integrated Gasification Combined Cycle Station Repower

Favorable Comments

- $\mathrm{OK}$ at existing combined cycle

- Large capacity and efficiency gain

- Fuel flexibility

- Low fuel cost

- Very low $\mathrm{SO}_{2}$ and $\mathrm{NO}_{\mathrm{x}}$ emissions.

- Coal is our primary fuel

- Combined cycle has good efficiency. Coal is our best cost fuel.

- This option was looked at in our 1993 integrated resource plan.

- Ability to add in steps, reliability
Unfavorable Comments

- Only at existing combined cycle plant

\section{Unfavorable Comments}

- High operating cost, could dramatically change capacity factor

- Minimal capital savings 


\begin{tabular}{|l|l|}
\hline 4th Ranked: HIPPS Station Repower & \multicolumn{1}{c|}{ Unfavorable Comments } \\
\hline Favorable Comments & $\begin{array}{l}\text { - Not very familiar } \\
\text { Have had no introduction to HIPPS until } \\
\text { now } \\
\end{array}$ \\
& $\begin{array}{l}\text { Efficiency improvement desirable but } \\
\text { needs to be proven }\end{array}$ \\
\hline
\end{tabular}

5th Ranked: Supplemental HRSG Repower

\begin{tabular}{|l|l|}
\hline \multicolumn{1}{|c|}{ Favorable Comments } & \multicolumn{1}{c|}{ Unfavorable Comments } \\
\hline $\begin{array}{l}\text { Can partially to fully repower existing } \\
\text { steam turbine generator }\end{array}$ & $\begin{array}{l}\text { - Low capacity and efficiency gain for } \\
\text { relatively high cost } \\
\text { Does not appear to be cost effective for } \\
\text { our system at this time }\end{array}$ \\
\hline
\end{tabular}

6th Ranked: Atmospheric Fluidized Bed Combustion System Station Repower

\section{Favorable Comments}

- Utilizes wide variety of fuels/coal

- Better $\mathrm{SO}_{2}$ and $\mathrm{NO}_{\mathrm{x}}$ emissions; low fuel cost

- Fuel versatility with coal; proven technology

- Economics

- This option was looked at in our 1993 integrated resource plan

- Ability to use at site

\section{Unfavorable Comments}

- Little or no capacity gain or efficiency gain

- Space limitations

- Too early to commit 
7th Ranked: Pressurized Fluidized Bed Combustion System Station Repower

\section{Favorable Comments}

- Moderate capacity gain

- Good efficiency gain

- Fuel flexibility

- Low fuel cost

- Low $\mathrm{SO}_{2}$ and $\mathrm{NO}_{\mathrm{x}}$ emissions

- May be economically favorable in some cases

- This option was looked at in our 1993 integrated resource plan

\section{Unfavorable Comments}

- Needs additional testing/operating maturity

- High capital cost

- Long lead time

- Solid waste disposal

- Unproven at large scale sizes; integration is questionable

- Space limitations

8th Ranked: Combustion Turbine Hot Windbox Repower

\begin{tabular}{|l|l|}
\hline \multicolumn{1}{|c|}{ Favorable Comments } & \multicolumn{1}{c|}{ Unfavorable Comments } \\
\hline - Optimum use of existing plant & $\begin{array}{l}\text { Limited improvement in efficiency for } \\
\text { cost of a new combustion turbine; okay if } \\
\text { combustion turbine is existing }\end{array}$ \\
- Low capacity and efficiency gain for \\
relatively high cost \\
- Not a lot of efficiency boost, with \\
increased emissions \\
- Does not appear to be cost effective for \\
our system at this time \\
Does hot windbox repowering fully fire a \\
steam turbine generator? If so, we do \\
not need that much capacity, we are \\
phasing in our capacity over a 7-year \\
period
\end{tabular}


9th Ranked (Least Favored): Combustion Turbine Feedwater Heating Repower

Favorable Comments

Unfavorable Comments

- Similar to HRSG repowering

- Low capacity and efficiency gain for relatively high cost

- Does not appear to be cost effective for our system at this time

- Not a lot of efficiency boost with increased emissions

- Not promising 


\subsection{WHAT RISK FACTORS AFFECT THE DECISION?}

2.8.1 Fuel Costs, Externalities and Deregulation. Respondents displayed a lack of consensus and certainty in their assessments of certain risk factors pertinent to a repowering decision. The strongest agreement related to gas prices, which, on average, respondents agreed would escalate greatly after 2005 compared to coal prices.

Exhibit 8

PERCEPTIONS ON RISK FACTORS

\begin{tabular}{|c|c|c|c|c|c|}
\hline \multicolumn{6}{|c|}{ Can you give your opinion on the following? } \\
\hline & $\begin{array}{c}1 \\
\text { strongly } \\
\text { disagree }\end{array}$ & $\begin{array}{c}2 \\
\text { disagree }\end{array}$ & $\begin{array}{c}3 \\
\text { neutral }\end{array}$ & $\begin{array}{c}4 \\
\text { agree }\end{array}$ & $\begin{array}{c}5 \\
\text { strongly } \\
\text { agree }\end{array}$ \\
\hline $\begin{array}{l}\text { Natural gas projects before year } \\
2005 \text { are risky investments } \\
2.6 \text { Avg/std dev. } 1.17 / 10 \text { responses }\end{array}$ & \multicolumn{5}{|c|}{$|\ldots \ldots \ldots \cdot \ldots \ldots|$} \\
\hline $\begin{array}{l}\text { Natural gas projects beyond } 2005 \\
\text { are risky investments } \\
\quad 3.1 \text { avg/std dev. } 0.99 / 10 \text { responses }\end{array}$ & \multicolumn{5}{|c|}{$|\ldots \ldots \cdot \ldots \ldots|$} \\
\hline $\begin{array}{l}\text { \$/Btu for gas and coal will diverge } \\
\text { greatly before year } 2005 \text { (gas will } \\
\text { get more expensive relative to } \\
\text { coal) } \\
\quad 2.9 \text { avg/std dev. } 1.10 / 10 \text { responses }\end{array}$ & \multicolumn{5}{|c|}{$|\ldots \ldots \cdot \ldots \ldots|$} \\
\hline $\begin{array}{l}\text { \$/Btu for gas and coal will diverge } \\
\text { greatly beyond year } 2005 \text { (gas will } \\
\text { get more expensive relative to } \\
\text { coal) } \\
3.8 \mathrm{avg} / \mathrm{std} \text { dev. } 0.92 / 10 \text { responses }\end{array}$ & & \multicolumn{4}{|c|}{$|\ldots \ldots \cdot \ldots \ldots|$} \\
\hline $\begin{array}{l}\text { Securing an adequate long-term } \\
\text { supply of gas can be done at } \\
\text { acceptable cost } \\
\quad 3.33 \mathrm{avg} / \mathrm{std} \text { dev. } 1.12 / 9 \text { responses }\end{array}$ & & \multicolumn{4}{|c|}{$|\ldots \ldots \cdot \ldots \ldots|$} \\
\hline $\begin{array}{l}\text { Some form of carbon tax or } \mathrm{CO}_{2} \\
\text { externality charge is likely } \\
2.6 \mathrm{avg} / \mathrm{std} \text { dev. } 1.07 / 10 \text { responses }\end{array}$ & \multicolumn{5}{|c|}{$|\ldots \ldots \cdot \ldots \ldots|$} \\
\hline $\begin{array}{r}\text { Coal projects are risky investments } \\
3.0 \mathrm{avg} / \mathrm{std} \text { dev. } 1.05 / 10 \text { responses }\end{array}$ & \multicolumn{5}{|c|}{$|\ldots \ldots \cdot \ldots \ldots|$} \\
\hline $\begin{array}{l}\text { Our company is deferring capital } \\
\text { investments until utility restructur- } \\
\text { ing implications are clear } \\
3.6 \mathrm{avg} / \mathrm{std} \text { dev. } 1.35 / 10 \text { responses }\end{array}$ & \multicolumn{5}{|c|}{$|\ldots \ldots \ldots \ldots, \ldots \ldots \ldots|$} \\
\hline
\end{tabular}


2.8.2 First-of-a-Kind HIPPS Risk Level. Respondents were in greater agreement about the form a HIPPS demonstration project should take and the risk that it should entail. They generally agreed that it should be a lower-risk, larger-scale repowering application.

\section{Exhibit 9}

\section{PERCEPTIONS ON A HIPPS DEMONSTRATION PROJECT}

Lower Risk Option: demonstrate $1400^{\circ}$ F HIPPS repowering with modest development and modest $10 \%$ improvement in heat rate

Higher Risk Option: demonstrate $1700^{\circ} \mathrm{F}$ HIPPS repowering with substantial improvement in heat rate

Can you give your opinion on the following?

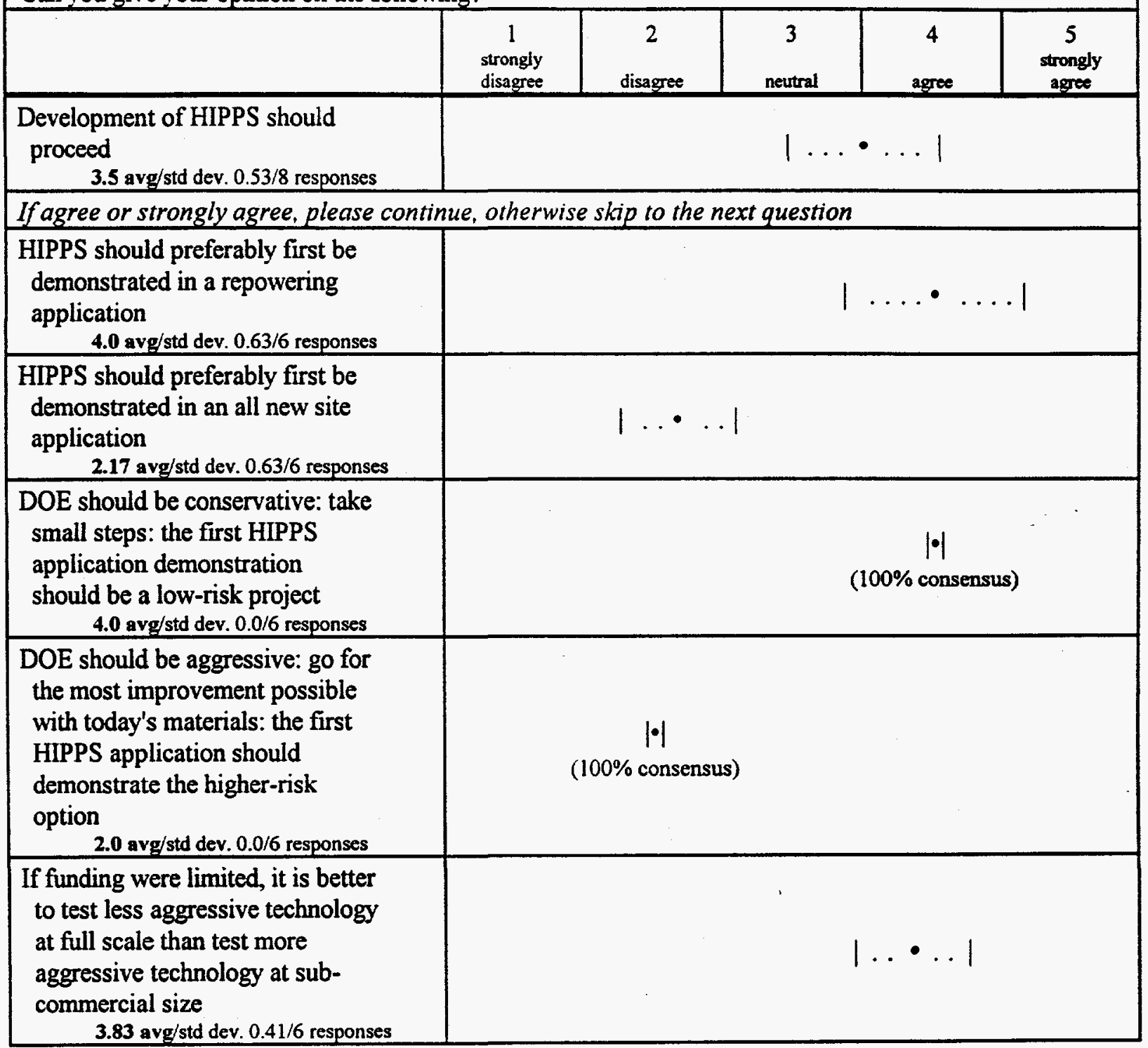




\section{Major Emphasis and Technical Concerns of HIPPS}

Approximately one-half of the survey participants felt adequately informed about HIPPS to provide opinions regarding the major emphasis on a HIPPS repowering demonstration and to list primary technical concerns for HIPPS.

For a demonstration of HIPPS, these respondents believed that:

- Overall cost (capital costs and operations and maintenance (O\&M) costs) must be minimized,

- The reliability of the high-risk components must be established,

- Low environmental emissions need to be demonstrated, and

- Cycle efficiency should be economically maximized.

The technical concerns of the survey participants included the following:

- Materials reliability at high-temperature,

- Cost (capital and O\&M) for repowering - the addition of many new and expensive components could make HIPPS a high-cost option,

- $\quad \mathrm{SO}_{\mathrm{x}}$ and $\mathrm{NO}_{\mathrm{x}}$ control,

- Cycle start-up time, cycling ability,

- $\quad$ Pyrolyzer performance and reliability, and

- Potential for peaking duty.

Other activities the participants felt DOE should sponsor include:

- Detailed cost assessments to identify feasibility and market acceptance compared to competing technologies,

- Continued support of advanced generation research to:

-- Increase efficiency

-- Decrease emissions

-- Make cost competitive,

- Improve emission performance via pre-combustion methods, and

- Evaluate potential for distribution generation.

\subsection{SENSITIVITY OF UNIT DISPATCH TO OPERATING COSTS}

A very important consideration in any repowering is the overall energy efficiency. High energy efficiency reduces fuel costs, which are usually the most significant element in operating cost. The lower the unit operating cost, the more hours per year the unit is called on to meet demand (dispatched), and the higher its capacity factor. Most repowering technologies improve unit energy efficiency, so (assuming the fuel price is not significantly different) the repowered unit can be expected to have more operating hours and be subjected to fewer start-stop cycles. Unit dispatch is assessed by utility company generation planning models over the projected life of the project to estimate yearly use levels. 
As an illustration, a representative curve of unit dispatch versus operating costs is shown as Exhibit 10.

Exhibit 10

TYPICAL OPERATING COSTS VERSUS ANNUAL HOURS OF OPERATION

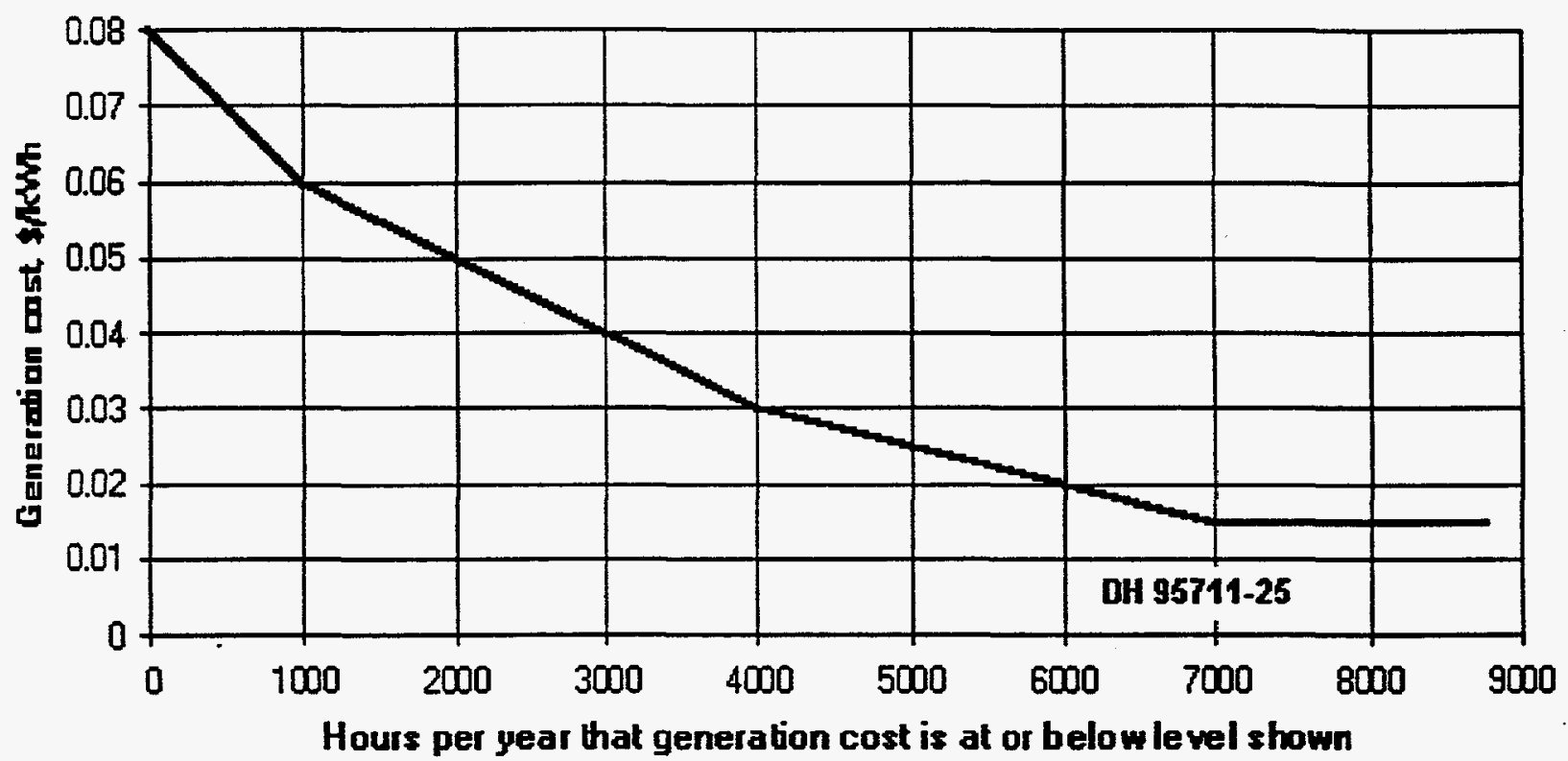

The survey participants were asked to estimate the sensitivity of unit dispatch to operating cost. Most participants chose not to provide this information since it is often considered a sensitive competitive issue. However, one participant provided the following breakdown, which shows a trend similar to that of Exhibit 10:

\begin{tabular}{ll} 
Hours per year & Operating cost range at or below: \\
\hline Above $4000 \mathrm{hrs} / \mathrm{yr}$ & $\$ 0.014-\$ 0.016$ per $\mathrm{kWh}$ \\
$500-4000 \mathrm{hrs} / \mathrm{yr}$ & $\$ 0.021-\$ 0.023 \mathrm{per} \mathrm{kWh}$ \\
below $500 \mathrm{hrs} / \mathrm{yr}$ & $\$ 0.033-\$ 0.036$ per $\mathrm{kWh}$
\end{tabular}

\subsection{SUMMARY OF SURVEY RESULTS}

The responses from electric utility companies provided extremely valuable guidance for a conceptual design study of repowering with HIPPS technology and resulted in the following major conclusions:

\section{Most important factors in considering a unit as a repowering candidate:}

1. The plant preferably was built between 1955 and 1965 .

2. Operating costs are not projected to remain competitive.

3. The boiler needs major maintenance/replacement.

4. The unit needs $\mathrm{SO}_{\mathrm{x}}$ emissions reduction.

4. The unit's heat rate needs to be improved.

6. The unit's rated output is generally between 50 and $200 \mathrm{MWe}$. 


\section{Most important factors for selecting a repowering technology:}

1. Proven reliability is the most important selection criterion. The utility companies need to be convinced of technical maturity.

2. The economics must be competitive after deregulation.

3. The capital and operating costs must be reasonable.

\section{Most favored repowering methods:}

1. Combustion turbine with new HRSG.

2. Repowering with an integrated gasification combined cycle.

3. HIPPS repowering. This option was rated "neutral" because of lack of familiarity. Respondents, on average, had less favorable opinions regarding all other repowering options.

\section{Least favored repowering methods:}

- Combustion turbine feedwater heating repowering.

- Combustion turbine hot windbox repowering.

\section{Perceived Risks:}

- Most utilities believe that natural gas projects before the year 2005 are not risky investments.

- The $\$ / B t u$ for gas and coal will diverge beyond year 2005 (gas will get more expensive relative to coal).

- Some companies are deferring capital investments until utility restructuring implications are clearer. 
A market assessment was conducted to estimate the number and characteristics of U.S. generating units that constitute the current, primary potential market for coal-based repowerings, including HIPPS-based approaches.

The U.S. population of coal-fired power plants was characterized using an existing data base. Results of the utility survey were then used to define the ages and sizes of units that utilities currently consider to be their primary candidates for repowering. The data base was then used again to determine the most likely plant characteristics for units of these ages and sizes.

This section describes the basis for the plant market assessment, the pre-selection criteria used, and the results of the assessment.

\subsection{DATA SOURCE FOR MARKET ASSESSMENT}

A commercially available electronic data base, The Electric Plant Data Base System ${ }^{6}$, was used to establish power plant characteristics that are representative of a typical repowering candidate and to estimate the number of U.S. units having these characteristics. Section 2.1 discussed the main characteristics of a power plant that are pertinent to a repowering evaluation. Of these, the following five are used by the data base to describe a generating unit:

- age,

- $\quad$ generating capacity,

- throttle steam design conditions,

- $\quad$ present fuel, and

- $\quad$ current operating status.

Therefore, these characteristics form the basis of the market assessment.

\subsection{PRE-SELECTION CRITERIA}

The assessment focused on the introduction of an advanced coal-fueled technology as a repowering technology, and as a new technology needing demonstration. This placed some constraints on the plants considered, namely:

- The site must be coal-fired, or designed for coal use, to be an economical candidate.

- Units built prior to 1940 are more likely to be too small, inefficient, old, and worn to be capable of long extensions in service. The study therefore evaluated units placed in service from 1940 to present. In the 2000-2010 time period many of these units will be approaching 
the end of their useful lives. They will need upgrade to continue operation, and will thus be candidates for repowering, life extension without repowering, or retirement. Over half the units in this category are below $200 \mathrm{MWe}$ in nameplate rating.

Exhibit 11 shows the fossil-fueled plant capacity in megawatts that was installed in the U.S. by year 1980 . From this exhibit, it is clear that virtually all fossil-fired, U.S. generating capacity entered service after 1945.

The population of existing power plants in the data base is limited to those located in the continental U.S. and operated by investor-owned electric utilities. This covers a very wide spectrum of unit-types, and is also likely to be representative of a significant number of industrial, municipal, and cooperative units.

\section{Exhibit 11}

FOSSIL PLANT GENERATION CAPACITY VERSUS YEAR OF STARTUP

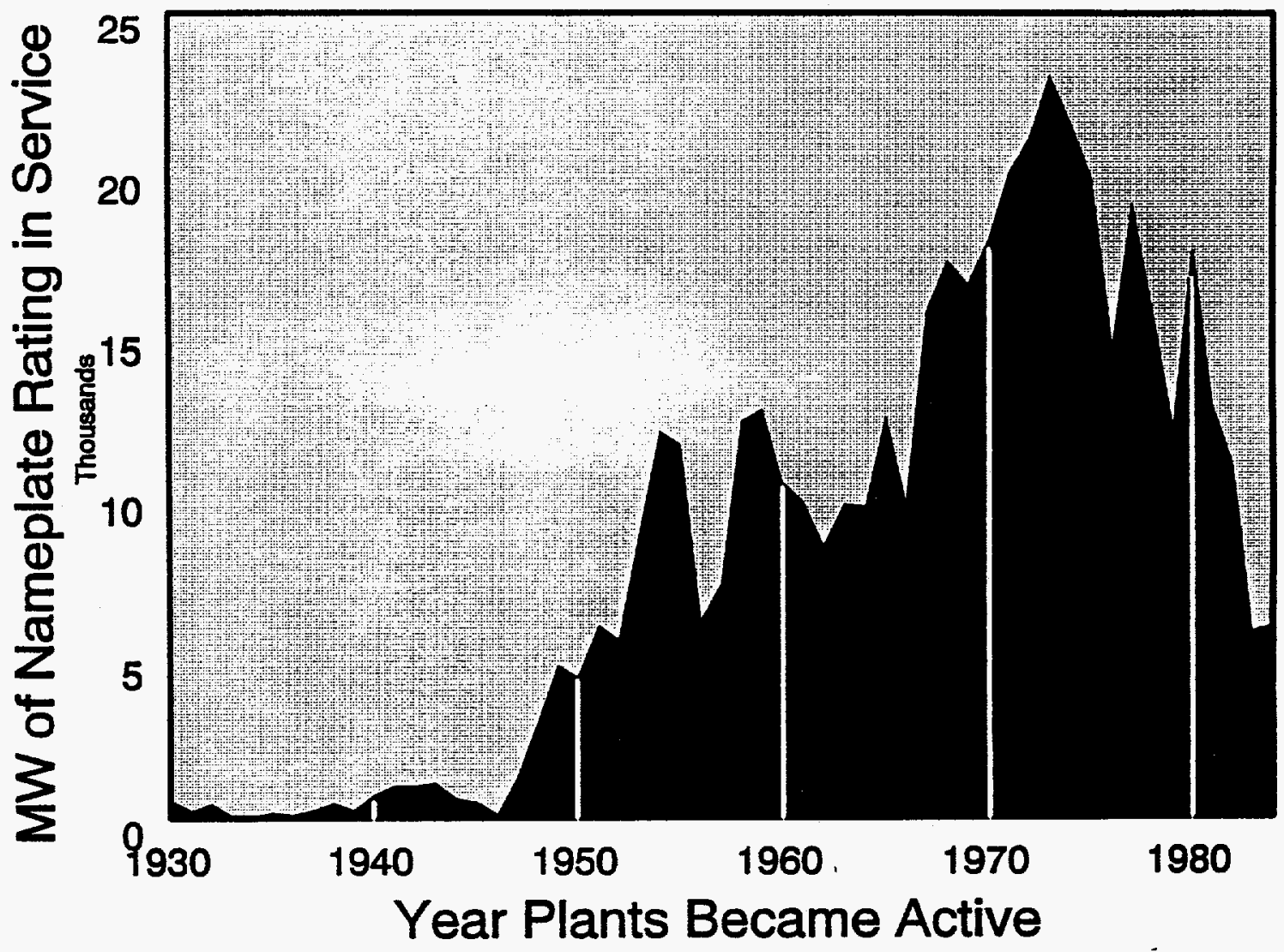

DH-93723-10a 


\subsection{UNIT AGE AND SIZE}

Exhibit 12 presents the number of retired (hatched) and operating (solid) coal-fired units commissioned since 1940 sorted by nameplate MWe rating. More than half of the units under 50 MWe and about $1 / 3$ of the 50-100 MWe units have already been retired, while most coal-fired units over $150 \mathrm{MWe}$ remain in service.

NUMBER OF U.S. COAL UNITS SORTED BY SIZE

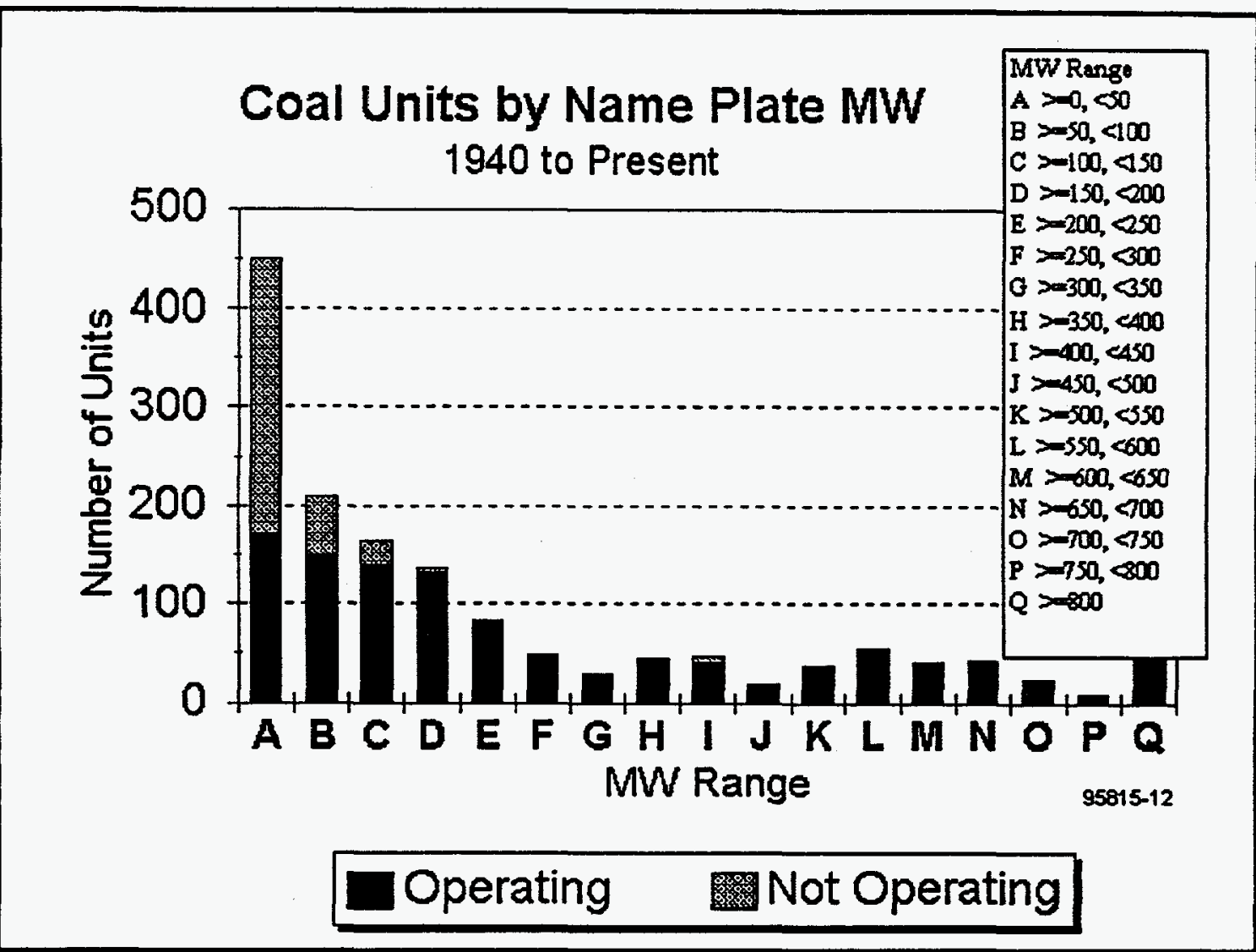

The average size of units installed in the U.S. has increased over time. So, although electric utilities built fewer units in later years, the units contribute substantially to the installed capacity. This is illustrated in Exhibits 13a through 13d.

The utility survey, described previously, shows that electric companies prefer consideration of 40- to 50 -year-old units as candidates for repowering. Focusing on the 1950s as the likely market, it is clear from Exhibit 13b that the vast majority of candidate units are below $200 \mathrm{MWe}$ in nameplate rating. 
Exhibit 13

NUMBER OF PRESENTLY OPERATING U.S. COAL-FIRED UNITS BY AGE AND SIZE

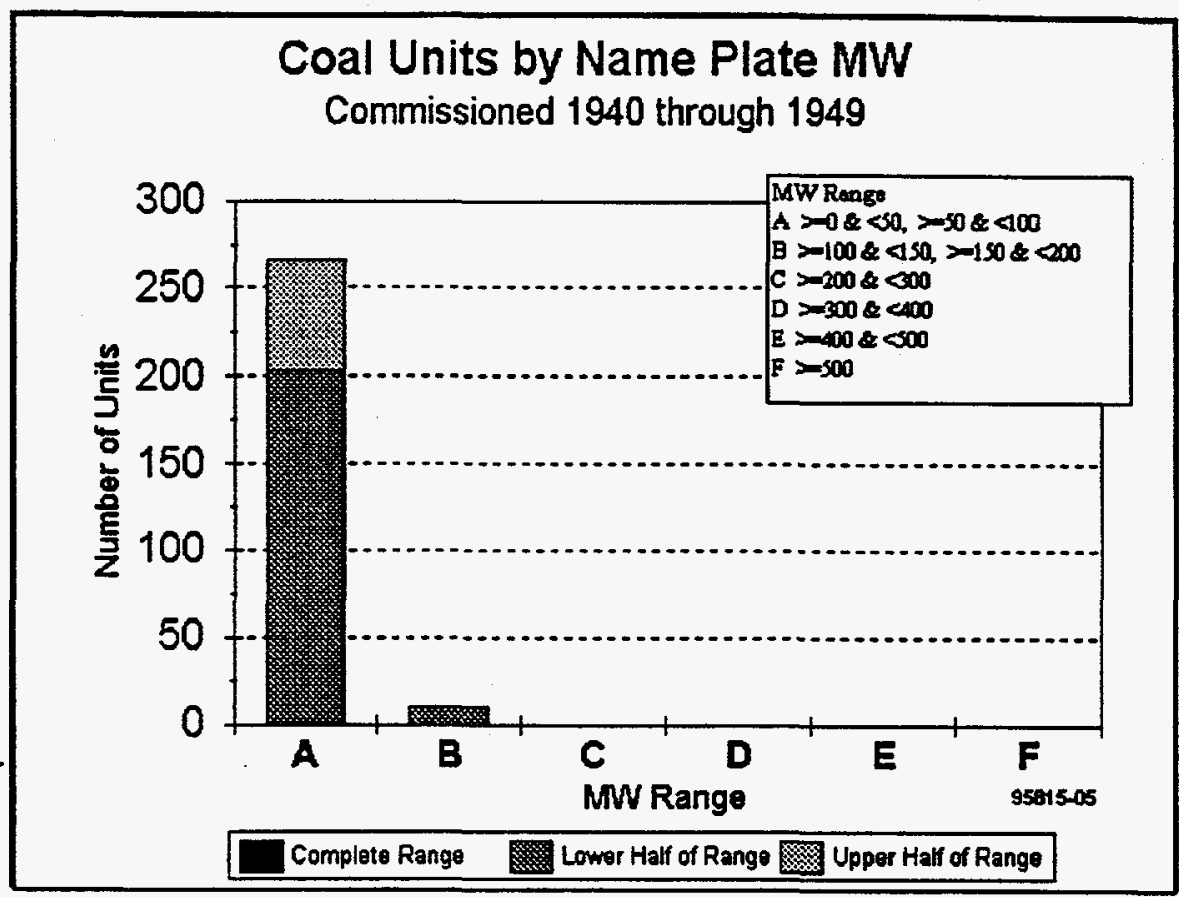

Exhibit 13a: 1940s Units

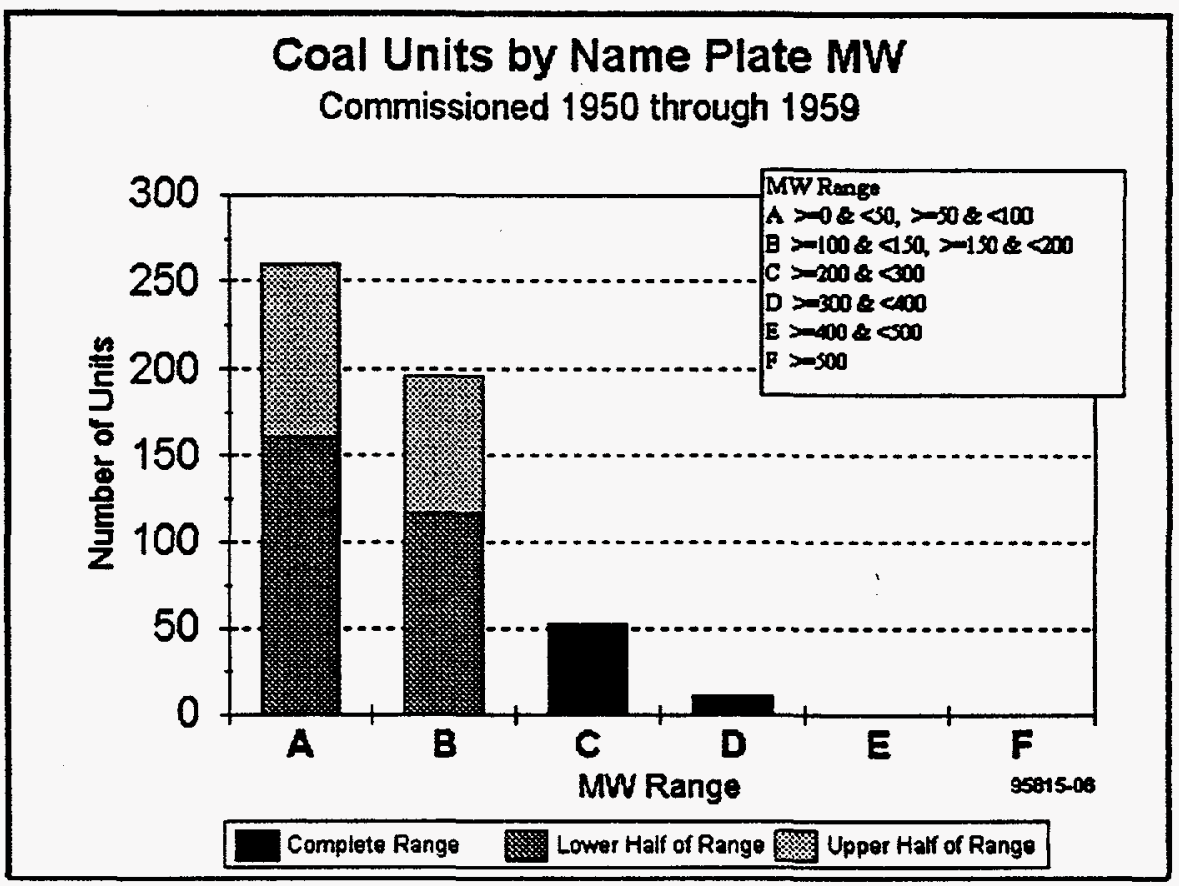

Exhibit 13b: 1950s Units 


\section{Exhibit 13 (Continued)}

\section{NUMBER OF PRESENTLY OPERATING U.S. COAL-FIRED UNITS BY AGE AND SIZE}

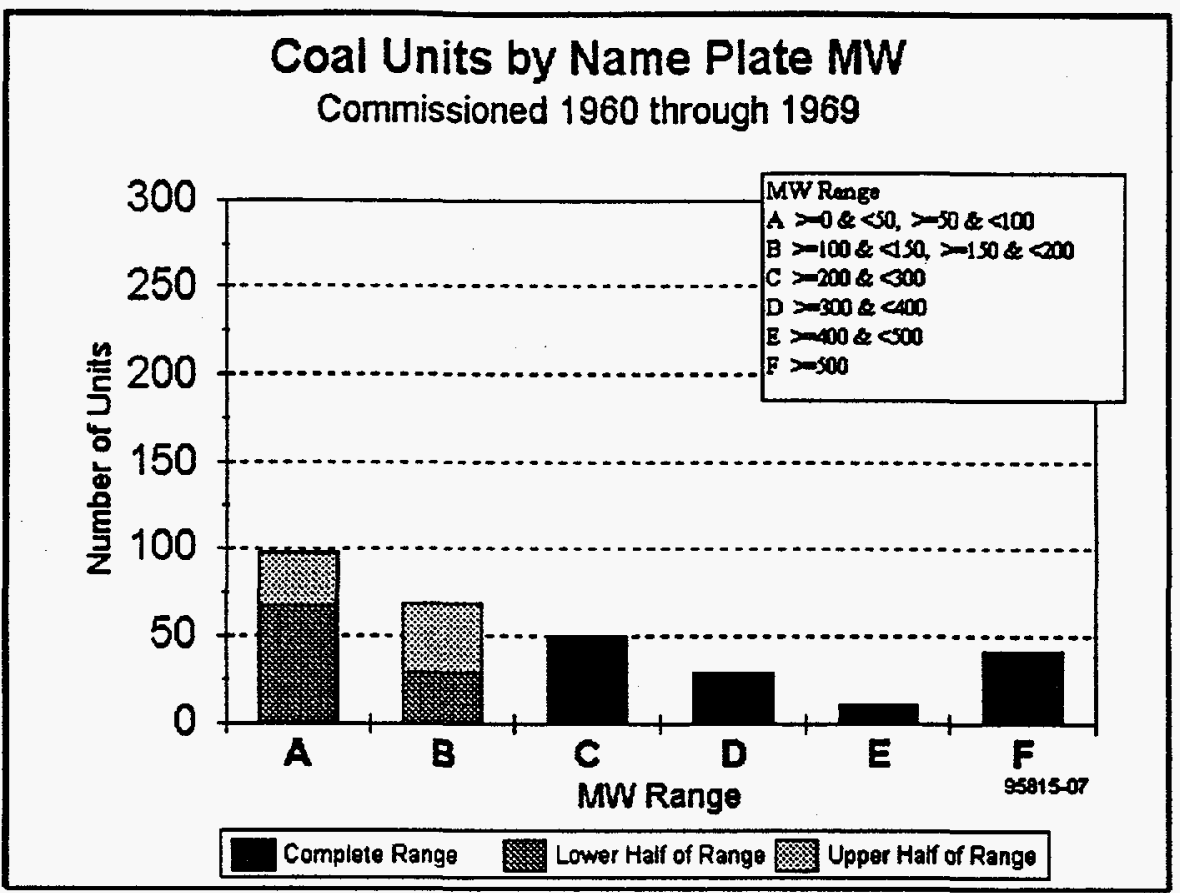

Exhibit 13c: 1960s Units

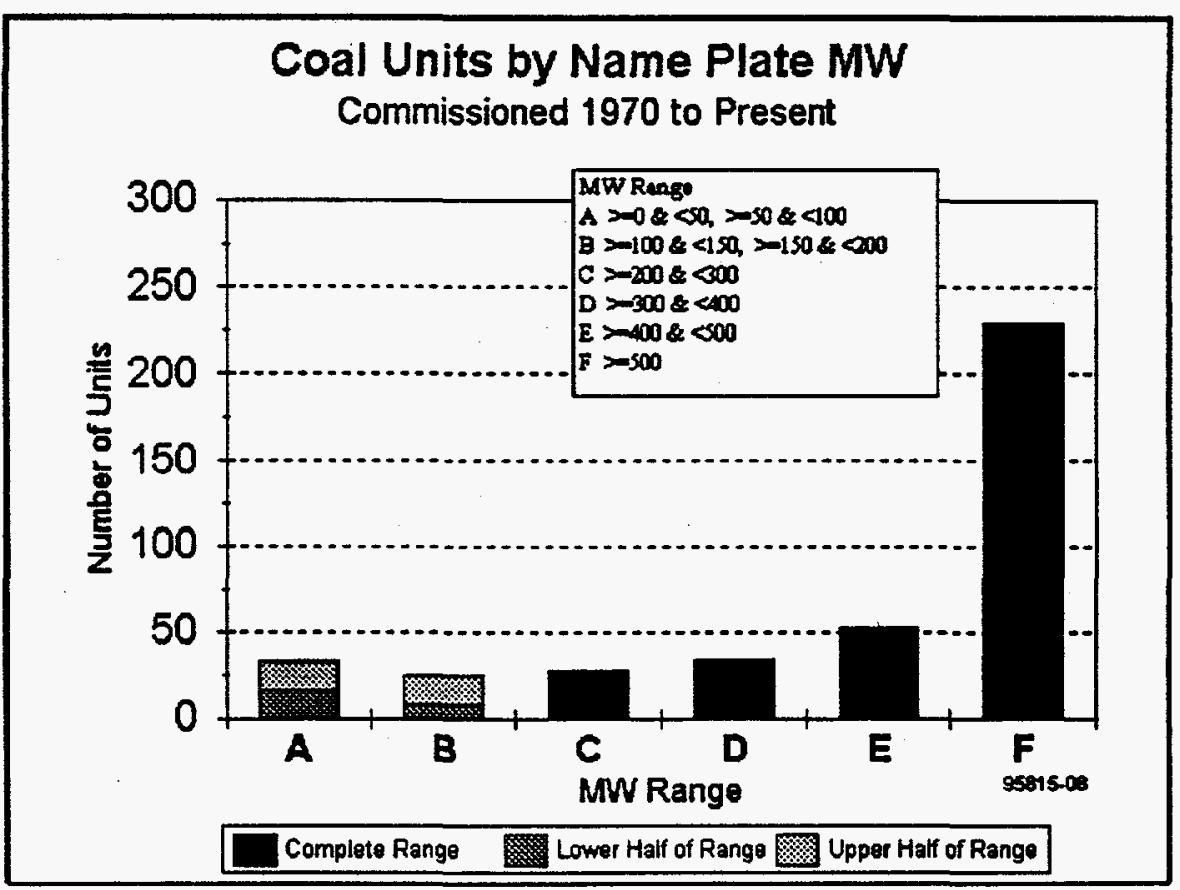

Exhibit 13d: Modern Units 


\subsection{REHEAT VERSUS NON-REHEAT}

Exhibit 14 shows the prevalence of reheat steam cycles in units between 50 and $200 \mathrm{MW}$ built after 1940. The data base was sorted on the presence $(73.7 \%)$ or absence $(26.3 \%)$ of a data-field value for reheat temperature. This does not necessarily mean that $26.3 \%$ of the power plant population does not have reheat. Rather, at least $73.7 \%$ of the unit population (larger than $50 \mathrm{MWe}$ but smaller than $200 \mathrm{MWe}$ ) is configured with reheat. An absent reheat temperature in the data base could mean that reheat is not currently used or that the reheat-temperature value was simply not supplied for the data base.

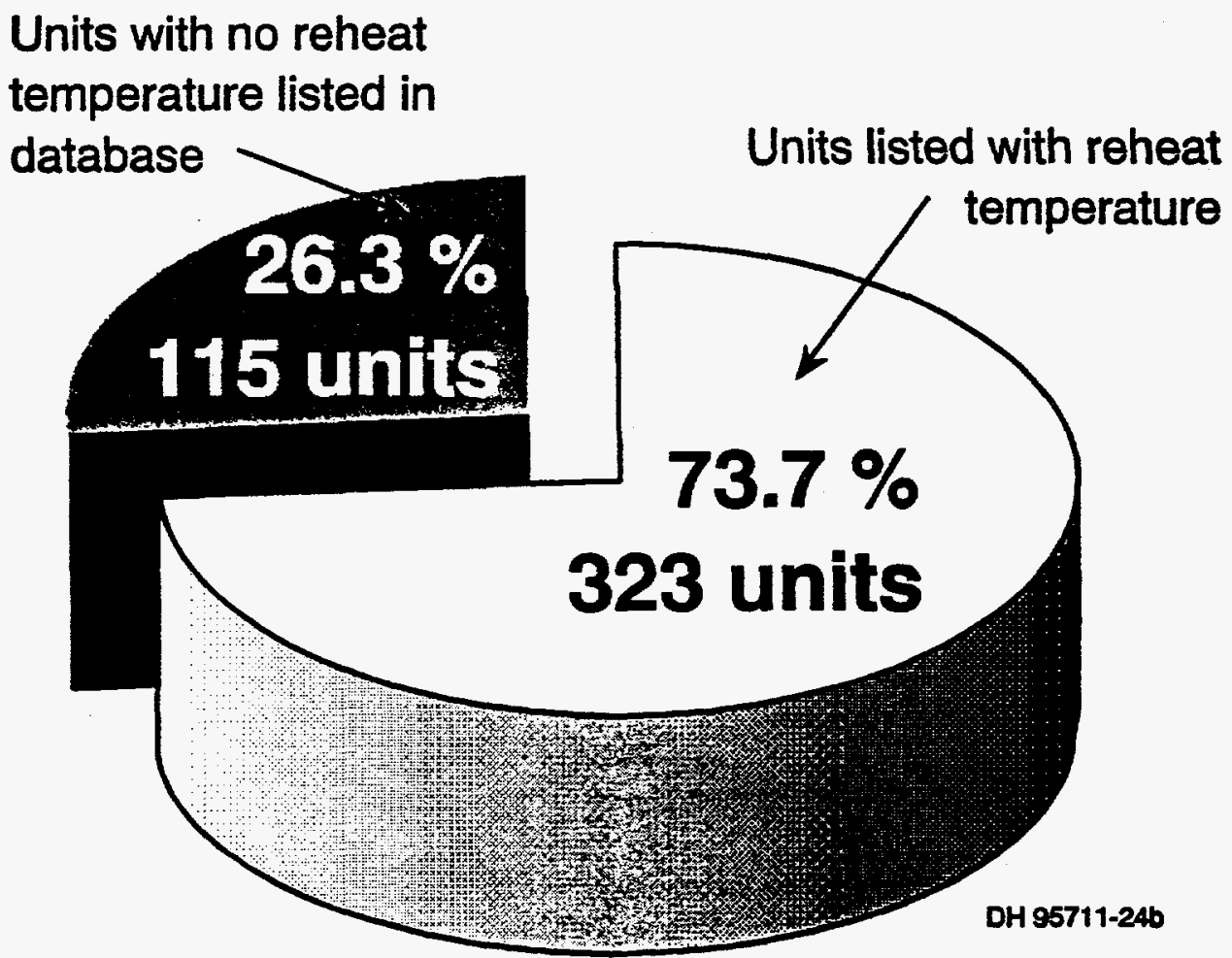

operational U.S. units between 50 to 200 MW output built after 1940 


\subsection{THROTTLE PRESSURE}

Exhibit 15 presents the distribution by unit size of design-basis throttle pressures for coal-fired units commissioned after 1940 . The most common throttle pressure is 1800 psig followed by 2400 psig, and then 1450 psig. The higher throttle pressures are common for larger units.

Exhibit 15

THROTTLE PRESSURE OF COAL-FIRED UNITS

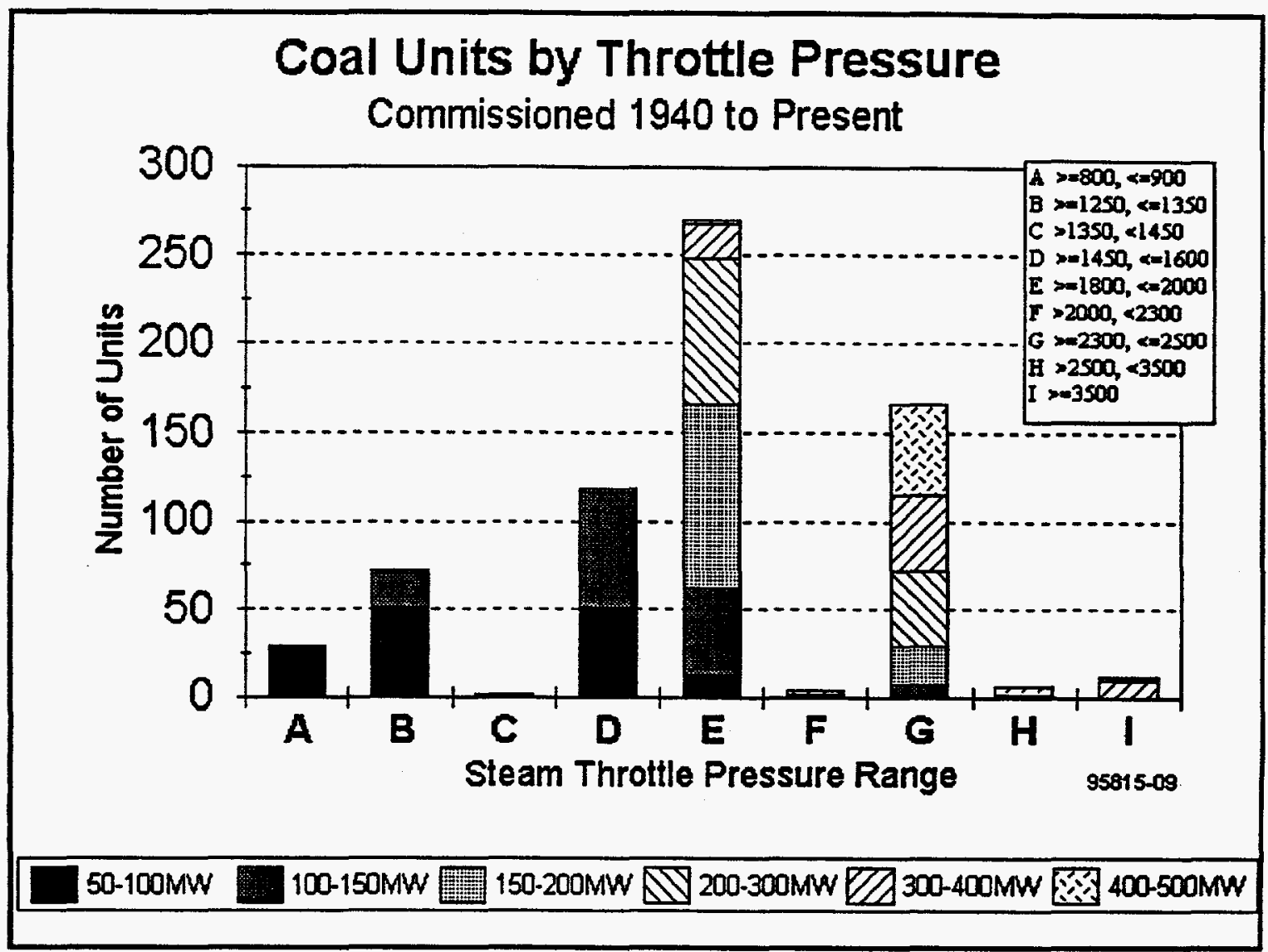




\subsection{THROTTLE TEMPERATURE}

Exhibit 16 presents the distribution of design superheat temperature of the units commissioned after 1940. A superheat of $1000^{\circ} \mathrm{F}$ is the dominant design selection.

\section{Exhibit 16}

SUPERHEAT TEMPERATURE OF COAL-FIRED UNITS

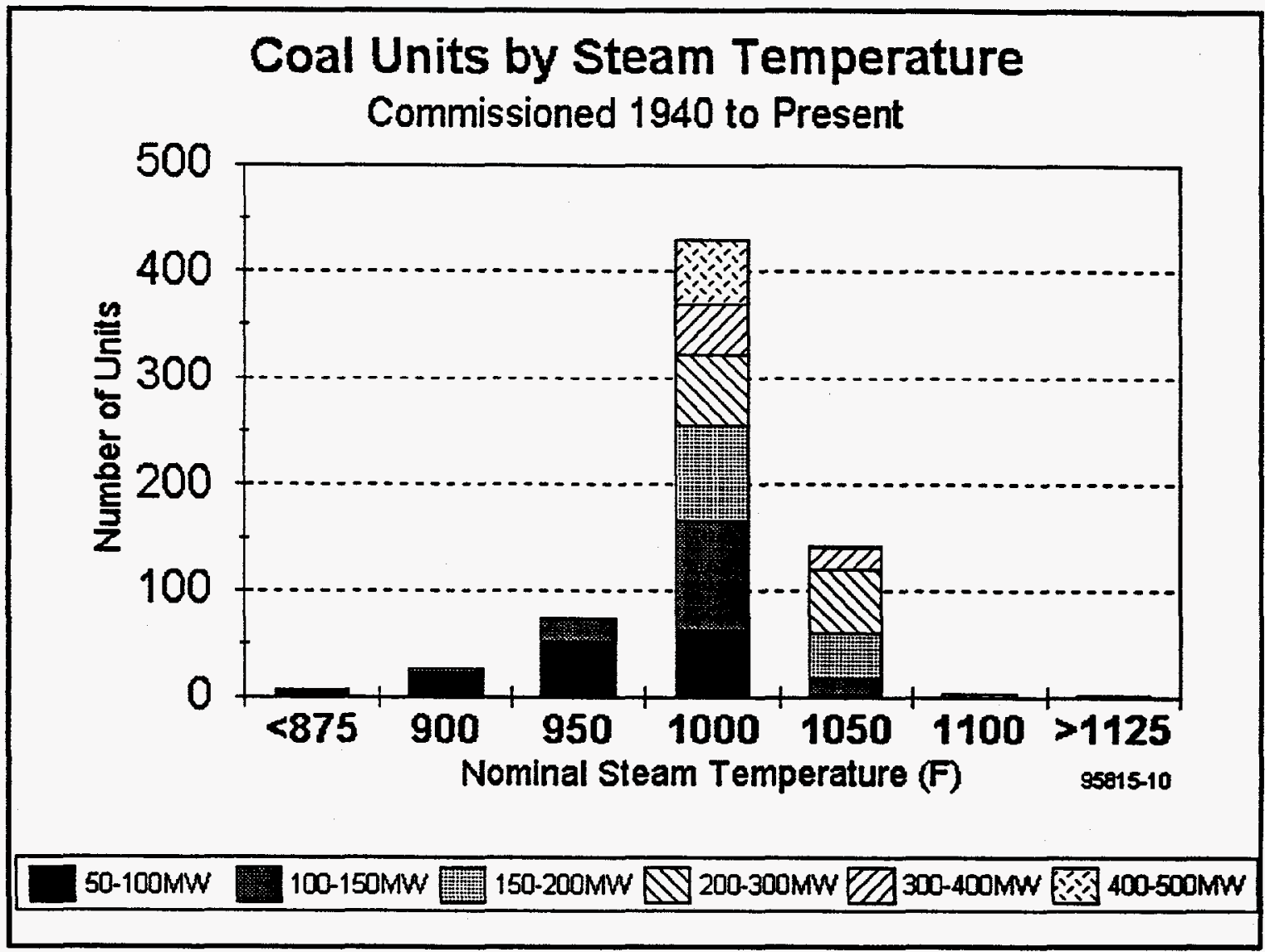

\subsection{REPRESENTATIVE PLANT POPULATION FOR REPOWERING}

Based on the market assessment that examined the characteristics of U.S. generating units, the following criteria were developed for candidate sites for repowering:

- Unit Size:

- 50 to $200 \mathrm{MWe}$ output

- Age:

- 1950's vintage (Typically about 40 years old as of 1995) 
- Steam Conditions:

- Subcritical single reheat units:

- $1450 \mathrm{psig} / 1000^{\circ} \mathrm{F} / 1000^{\circ} \mathrm{F}$ (lower size range),

- $1800 \mathrm{psig} / 1000^{\circ} \mathrm{F} / 1000^{\circ} \mathrm{F}$ (mid size range), or

- $2400 \mathrm{psig} / 1000^{\circ} \mathrm{F} / 1000^{\circ} \mathrm{F}$ (larger size range)

- Alternative steam conditions are $1050^{\circ} \mathrm{F} / 1050^{\circ} \mathrm{F}$ and $1000^{\circ} \mathrm{F} / 1050^{\circ} \mathrm{F}$

- Fuel:

- Presently coal-fired.

There are about 246 units in the U.S. that meet these criteria. These units currently constitute the primary potential market for coal-based repowerings. Internationally, hundreds of similar units are candidates for repowering. 
The following items were used as references in this section:

1. Klara, J.M., "HIPPS: Beyond State of the Art, Part I," Power Engineering, December 1993, pp. 37-39.

2. Klara, J.M., "HIPPS Can Compete with Conventional PC Systems, Part II," Pewer Engineering, January 1994, pp. 33-36.

3. IEA Coal Research Newsletter. No. 6, Nov. 1991.

4. Based on information listed in: Electrical World Directory of Electric Utilities, 103rd Edition, 1995.

5. Based on information listed in: Electric Power Monthly, DOE/EIA 0226(95/04), April 1995.

6. Utility Data Institute, Electric Plant DATAPAK Data Base System, 1200 G Street, N.W., Suite 250, Washington, D.C., 20005, McGraw-Hill, Inc. 


\section{ABBREVIATIONS USED IN THIS REPORT}

$\begin{array}{ll}\text { Abbreviation } & \text { Meaning } \\ \text { AFBC } & \text { atmospheric fluidized bed combustion } \\ \text { avg } & \text { average } \\ \text { CAAA } & \text { Clean Air Act Amendments of 1990 } \\ \text { CT } & \text { combustion turbine (a synonym for gas turbine) } \\ \text { DOE } & \text { United States Department of Energy } \\ \text { FWDC } & \text { Foster Wheeler Development Corporation } \\ \text { GT } & \text { gas turbine (a synonym for combustion turbine) } \\ \text { HIPPS } & \text { high performance power system } \\ \text { HRSG } & \text { heat recovery steam generator } \\ \text { IGCC } & \text { integrated gasification combined cycle } \\ \text { LEBS } & \text { low emission boiler system } \\ \text { n/a } & \text { not applicable } \\ \text { MM } & \text { million, 10 } \\ \text { NO } & \text { nitrogen oxides } \\ \text { PETC } & \text { Pittsburgh Energy Technology Center of the U.S. DOE } \\ \text { PFBC } & \text { pressurized fluidized bed combustion } \\ \text { SO } & \text { sulfur oxides } \\ \text { ST } & \text { steam turbine } \\ \text { std dev. } & \text { standard deviation } \\ \text { ST-G } & \text { steam turbine-generator } \\ \text { U.S. } & \text { the United States of America } \\ \text { UTRC } & \text { United Technologies Research Center }\end{array}$

